\title{
The Immunologic Basis for Severe Neonatal Herpes Disease and Potential Strategies for Therapeutic Intervention
}

\author{
Soren Gantt ${ }^{1}$ and William J. Muller ${ }^{2}$ \\ ${ }^{1}$ Department of Pediatrics, Division of Infectious Diseases, University of Washington and Seattle Children's Hospital, \\ Seattle, WA 98105, USA \\ ${ }^{2}$ Department of Pediatrics, Division of Infectious Diseases, Northwestern University Feinberg School of Medicine, \\ Chicago, IL 60611, USA \\ Correspondence should be addressed to Soren Gantt; sgantt@uw.edu
}

Received 4 January 2013; Accepted 6 March 2013

Academic Editor: Tobias R. Kollmann

Copyright (c) 2013 S. Gantt and W. J. Muller. This is an open access article distributed under the Creative Commons Attribution License, which permits unrestricted use, distribution, and reproduction in any medium, provided the original work is properly cited.

\begin{abstract}
Herpes simplex viruses types 1 and 2 (HSV-1 and HSV-2) infect a large proportion of the world's population. Infection is life-long and can cause periodic mucocutaneous symptoms, but it only rarely causes life-threatening disease among immunocompetent children and adults. However, when HSV infection occurs during the neonatal period, viral replication is poorly controlled and a large proportion of infants die or develop disability even with optimal antiviral therapy. Increasingly, specific differences are being elucidated between the immune system of newborns and those of older children and adults, which predispose to severe infections and reflect the transition from fetal to postnatal life. Studies in healthy individuals of different ages, individuals with primary or acquired immunodeficiencies, and animal models have contributed to our understanding of the mechanisms that control HSV infection and how these may be impaired during the neonatal period. This paper outlines our current understanding of innate and adaptive immunity to HSV infection, immunologic differences in early infancy that may account for the manifestations of neonatal HSV infection, and the potential of interventions to augment neonatal immune protection against HSV disease.
\end{abstract}

\section{Introduction}

Young infants are highly vulnerable to infections due to changes that occur in the immune system during the transition from fetal to postnatal life [1-3]. Herpes simplex virus (HSV) infection exemplifies this paradigm [4]. When HSV infection occurs within the first several weeks of life, the majority of infants will die without treatment. However, acquisition of HSV after this period is typically mild or even asymptomatic. In this paper, we explore what is known about mechanisms by which immunologic control of HSV infection may be impaired in early infancy. Furthermore, we discuss the implications of these findings for developing interventions to better prevent and treat neonatal HSV infection and suggest directions for future research.

\section{Herpes Simplex Virology and Pathogenesis}

The herpes simplex viruses (HSV-1 and HSV-2) are members of the neurotropic $\alpha$-herpesvirus subfamily of the Herpesviridae family of viruses (reviewed in $[5,6]$ ). This family includes a variety of enveloped, icosahedral capsid-containing, linear double-stranded DNA viruses with relatively large genomes, many of which cause diverse diseases in humans. All members of the family share the capacity to remain latent in the infected host and are capable of periodic reactivation and spread to new hosts.

Outside the newborn period, primary infection in immunocompetent individuals may cause gingivostomatitis, pharyngitis, or ulcerative genital lesions [7], but infection is frequently subclinical $[8,9]$. In most chronically 
infected individuals, reactivation of virus is either asymptomatic or at most leads to bothersome mucosal lesions [10].

Spread of HSV within the population generally results from reactivation of virus from latently infected neurons within sensory ganglia and anterograde axonal transport to the innervated mucosa, with subsequent viral replication in the epithelium and shedding [11]. The grouped vesicular and/or ulcerative lesions typical of HSV may or may not occur during these episodes, and subclinical genital shedding of HSV-2 is as common in those without any history of genital lesions as it is in those with such a history [12]. Episodes of asymptomatic genital shedding appear to decrease over time, with reactivation occurring more than twice as often in the first three months after primary first-episode HSV-2 genital infections than in subsequent three-month periods [13]. However, short bursts of asymptomatic viral reactivation occur surprisingly frequently for both oral and genital HSV, with about half of genital mucosal reactivations lasting less than 12 hours and more than $70 \%$ of these episodes occurring without symptoms [14].

\section{Epidemiology and Clinical Manifestations of Neonatal HSV Infection}

HSV infections are common, with seroprevalences in American adults of about $60 \%$ for HSV-1 and 17\% for HSV-2 [15]. HSV generally initiates infection at mucosal surfaces and spreads along sensory neurons to establish latency within ganglia (typically the trigeminal or sacral ganglia) [16]. Neonatal HSV infection (defined as occurring before 28 days after birth) occurs in between 1 in 12,500 and 1 in 1,700 live births in the United States, which in combination with its high morbidity makes it a major public health concern (reviewed in [4]). Less than half of neonatal HSV infections occur in the setting of long-standing maternal infection, with a risk of transmission of $<1 \%$ even when virus is detectable in the maternal genital tract at the time of delivery. In contrast, when a woman acquires HSV late in pregnancy, the risk of neonatal HSV is $25 \%-50 \%$; this scenario accounts for about $50 \%-80 \%$ of all cases of neonatal HSV [4]. The difference in transmission risk between women with established and recent HSV infections suggests the importance of transplacental maternal antibody [17-21], as discussed in greater detail later, as well as the higher viral titers present during primary maternal infection.

HSV-1 is commonly associated with oral mucosal infection and HSV-2 with genital infection. However, genital infection with HSV-1 is increasing in prevalence, with recent studies suggesting it surpasses HSV-2 as a cause of genital infection in several different populations [22-29]. It has been speculated that this observation is related to a recent trend of acquiring oral HSV-1 infection later in life along with an increase in oral sex in young adults; this results in a population susceptible to genital HSV-1 infection at initiation of sexual activity [30]. Importantly, several studies suggest that both symptomatic and asymptomatic genital shedding of
HSV-1 is less frequent than that of HSV-2 [13, 31-33], which may have implications for neonatal infection.

3.1. In Utero Infection. Intrauterine HSV infection is associated with hydrops fetalis and fetal death. Surviving infants of in utero HSV infection have symptoms at birth similar to other congenital infections, including microcephaly, hydranencephaly, chorioretinitis, and rash, although the presentation is highly variable $[18,79]$. Although it is highly morbid, in utero HSV infection accounts for $<5 \%$ of all neonatal cases, or approximately 1 per 250,000 deliveries [80, 81]. It is unclear why fetal infection occurs so infrequently, for example, compared to cytomegalovirus, but multiple factors may be involved [82]. First, detection of HSV DNA in peripheral blood, though relatively common during primary infection, is rare during established disease, even with clinical reactivations [83]. Second, the maternal-placental interface appears to have fairly effective mechanisms to block the spread of HSV. Interestingly, even in cases with severe or disseminated maternal HSV infection during pregnancy, the fetus is often spared [84]. HSV DNA can be detected by PCR in a surprising proportion of placentas (roughly 10\%) [85, 86]. Immunohistochemical detection of HSV antigen is less common in placentas, but small foci of virus may be detected in the maternal decidua adjacent to the placenta [86].

3.2. Intrapartum and Postpartum Infection. The majority (roughly $85 \%$ ) of neonatal HSV infections are acquired during passage through the birth canal $[19,87]$. Only approximately $10 \%$ of neonatal HSV infections occur in the postpartum period, generally through contact with virus shed by caregivers, and these are typically caused by HSV-1. Infection of the newborn is thought to occur through mucosal (eyes, mouth) or cutaneous inoculation.

Neonatal HSV disease is classified into three clinical syndromes: localized skin, eye, and mouth (SEM); central nervous system (CNS) involvement with or without SEM; disseminated disease, which involves spread to visceral organs. Disseminated disease may or may not involve the CNS and can lead to hepatitis, pneumonitis, disseminated intravascular coagulation, shock, and multiple organ dysfunction syndrome. SEM disease accounts for approximately $45 \%$ of neonatal HSV cases, though these infants often progress to CNS or disseminated disease in the absence of treatment. CNS and disseminated disease represent approximately $30 \%$ and $25 \%$ of cases, respectively. Either HSV-1 or HSV-2 can cause SEM, CNS, or disseminated disease, although CNS infection with HSV-2 has been associated with greater morbidity [4, 88-90]. Newborns with severe HSV infection frequently present without fever or skin lesions. Delayed diagnosis and initiation of therapy occur often and contribute to poor outcomes [88]. Even with optimal treatment $(60 \mathrm{mg} /$ $\mathrm{kg} /$ day of intravenous acyclovir for 21 days), mortality is still approximately $6 \%$ with CNS disease and $>30 \%$ with disseminated disease [4]. Furthermore, treatment has had little effect on neurologic morbidity among survivors of CNS disease [91]. Encouragingly, recent studies have shown that suppressive oral antiviral therapy can improve long-term 
neurologic outcomes after CNS disease; however, abnormal neurologic outcomes were still reported for $31 \%$ of newborns with a history of HSV encephalitis who received suppressive treatment [92]. Thus, additional strategies are needed to better prevent and treat neonatal HSV infection.

\section{Immune Control of HSV Infection}

Despite intense study, our understanding of immunologic control of primary and recurrent HSV infections in humans remains incomplete. Virtually every aspect of immune defense appears to be involved in control of HSV infection, from antimicrobial peptides (AMPs; reviewed in [93]) through the intrinsic antiviral responses of infected cells (reviewed in [94]), innate immune effector cells and cytokines [95, 96], adaptive cellular responses [97, 98], and humoral responses [99]. In immunocompromised humans, defects in multiple arms of the immune response have been described as leading to severe HSV disease, including deficiencies in AMPs $[100,101]$, various defects in signaling (including signals mediated by TLR3 [102-107], STAT1 [108], tyrosine kinase 2 [109], and NF- $\kappa \mathrm{B}$ [110]), other mutations affecting lymphocyte function [111], and abnormalities in numbers or function of NK cells $[49,50]$, plasmacytoid dendritic cells (pDCs) [112, 113], and T cells [97].

Studies in animal models of HSV infection have shed light on the interaction of innate and adaptive immunity in the response to primary infection. The pattern recognition receptors (PRRs) that have been reported to recognize HSV include TLR2, TLR3, TLR9, the RIG-I-like receptors (RLRs) RIG-I and melanoma differentiation-associated gene 5 (MDA5 or interferon (IFN) induced with helicase C domain 1 (IFIH1)), NOD-like receptors (NLRs), interferon-inducible protein 16 (IFI16), the helicase Ku70, DNA-dependent activator of IFNregulatory factors (ZBP1), and the helicases DEAH box 9, DEAH box 36, and DDX60 (reviewed in $[43,44]$ ). HSV is capable of infecting monocyte-derived dendritic cells (DCs), including Langerhans cells in the skin and vaginal mucosal epithelia, inducing partial maturation but ultimately leading to apoptosis [114]. Migratory submucosal or dermal DCs phagocytose apoptotic debris, including HSV antigen, and migrate to draining lymph nodes $[115,116]$. These cells then appear to either transfer antigen to resident DCs within the lymph node for priming of effective $\mathrm{CD} 8^{+} \mathrm{T}$ cell responses [117] or in some situations will themselves contribute to priming of $\mathrm{CD}^{+}$and $\mathrm{CD} 8^{+}$responses [118].

T cell responses against HSV in humans are polyfunctional [119] and directed against a wide array of viral epitopes [120]. Infiltration of HSV-specific T cells into infected tissue initially involves $\mathrm{CD} 4^{+} \mathrm{T}$ cells, which in mice are required for subsequent $\mathrm{CD}^{+} \mathrm{T}$ cell entry into the mucosa [121]. Local NK cells likely contribute to control of HSV replication early in infection and make some IFN- $\gamma$ in the infected tissue [51], but IFN- $\gamma$ from infiltrating $\mathrm{CD} 4^{+} \mathrm{T}$ cells and production of CXCR3-dependent chemokines (likely by epithelial cells) are required for $\mathrm{CD}^{+} \mathrm{T}$ cells to efficiently enter the vaginal mucosa [121]. The chemokine gradient required for proper migration of $\mathrm{T}$ cells to the site of infection is coordinated in part by regulatory $\mathrm{T}$ cells (Tregs) [75].

HSV-specific $\mathrm{CD}^{+} \mathrm{T}$ cells appear to be the central effectors controlling latent HSV infection in neurons. In mice, activated $\mathrm{HSV}$-specific $\mathrm{CD}^{+} \mathrm{T}$ cells are retained in latently infected sensory ganglia, blocking viral reactivation through IFN- $\gamma$ production without killing the neurons $[122,123]$. A reduction in these cells can be seen in conditions of stress, leading to viral reactivation [124]. Recurrence of HSV lesions in skin and mucosa after reactivation from latency also activates local NK cell responses and memory $\mathrm{CD} 4^{+} \mathrm{T}$ cells, followed by infiltration of virus-specific $\mathrm{CD}^{+} \mathrm{T}$ cells, in a manner similar to primary infection $[125,126]$. Coordination of cellular responses to HSV reactivation in the skin and mucosa is also largely mediated by DCs, in conjunction with B cells $[127,128]$. Memory $\mathrm{CD}^{+} \mathrm{T}$ cells in mice are restimulated to produce IFN- $\gamma$ by local MHC-II ${ }^{+}$DCs and B cells [127]. Memory $\mathrm{CD}^{+}{ }^{+} \mathrm{T}$ cell responses are also initiated by tissueresident DCs, without requiring DC migration to draining lymph nodes [128]. In humans, infiltrating virus-specific $\mathrm{CD}^{+} \mathrm{T}$ cells persist at the dermal-epidermal junction for weeks after virus has been cleared, localizing to peripheral nerve endings [56]. Evidence suggests that these cells may be frequently exposed to viral antigen even in the absence of lesions [129], consistent with observations of frequent short bursts of asymptomatic HSV shedding at mucosal surfaces [14]. Modeling studies based on human data suggest that the local immune response is the critical determinant of genital HSV-2 shedding episodes and the development of lesions [57].

In the central nervous system, innate immune signaling through the TLR3 pathway is clearly important in controlling HSV replication during both primary infection and recurrence. Humans with specific defects affecting TLR3 signaling have increased susceptibility to encephalitis, with mutations described in UNC93B [103], TRAF3 [104], TRIF [105], and TLR3 [106, 107]. In mice, TLR2 signaling appears to be important in controlling HSV replication in the brain [130]. Interestingly, however, TLR2 has also been described as contributing to lethality of mice with HSV infection in the central nervous system by dramatically increasing the inflammatory response [131], in a manner regulated by the surface glycoprotein CD200R1 [132]. This concept that CNS inflammation can promote pathogenesis in HSV encephalitis is supported by other murine studies $[65-67,133]$.

Given that the human immune system directs multiple varied mechanisms at detection and control of HSV infection, it is not surprising that the virus allocates a significant proportion of its genome to overcoming the anti-HSV immune response. HSV modulation of immune responses essentially begins from the time the virus encounters a susceptible cell. Engagement of the HSV entry receptor known as herpes virus entry mediator (HVEM) modifies expression of a number of cellular genes, which may immediately alter the cell environment to promote viral replication [134] or alter mucosal chemokine and cytokine production [135]. These consequences of the HSV-HVEM interaction are thought to be due to transient NF- $\kappa$ B activation, which at later times after infection may promote viral gene expression in addition 
to modifying expression of cellular targets of NF- $\kappa \mathrm{B}$ [136]. Subsequently, the viral "virion host shutoff" protein (vhs), which is delivered to the cell within the tegument of the viral particle, promotes degradation of cellular mRNA, inhibiting synthesis of a variety of inflammatory proteins including cytokines and type I IFNs [137]. Additional proteins are expressed relatively early in infection to target different intrinsic antiviral cellular responses, inhibiting various proinflammatory and proapoptotic signaling proteins such as PKR and IRF3, and inhibiting type I IFN signaling pathways by mechanisms such as repression of STAT1 activation [94]. Other innate and adaptive immune responses are also targeted by HSV proteins, including binding of complement by the glycoprotein C (gC) $[138,139]$, binding of the Fc domain of IgG by the gE/gI complex [140], and interference with TAPmediated peptide loading onto class I MHC by ICP47 [141143].

In addition to suppression of cellular production of antiviral proteins, recent work suggests that other cellular processes intended to inhibit viral replication are targeted by HSV. There has been increasing appreciation of the importance of autophagy in resistance to HSV infection [144], particularly in neurons. HSV needs to evade autophagy to cause encephalitis [38], and the virus encodes at least two proteins which target this process. HSV ICP34.5 protein binds and inhibits the cellular autophagy protein Beclin-1 to promote neurovirulence [39], and US11 directly binds and inhibits the double-stranded RNA-dependent kinase PKR, which functions in induction of the autophagic response [40]. Importantly, neurons, in contrast to mucosal cells, require autophagic activity to limit HSV replication but do not respond effectively to stimulation by type I IFN [145].

\section{Aspects of HSV Immunity Specific to Neonates}

Human fetuses and newborn infants are more susceptible to severe infection with a wide variety of different pathogens compared to older children or adults. Fetal and neonatal immune responses have long been recognized to have qualitative differences that change during infancy, and we are beginning to understand the mechanisms that underlie this process (reviewed in [1-3]). The immunology of the young infant is dynamic and complex; for example, some innate responses become more "adult-like" within weeks, while others take a year or more [3, 146-149]. Beyond several weeks of life, acquiring HSV portends virtually none of the severe risks of neonatal infection [150]. In comparison, the risk of progression from tuberculosis infection to active disease remains elevated until approximately 4 years old $[149,151]$.

Fetal immunology likely represents an evolutionary strategy that contributes to successful parturition through maternofetal tolerance. The fetus and its mother are haploidentical, and thus have the potential for alloreactive responses akin to rejection. Inflammation is generally harmful to the developing fetus, resulting in a number of adverse outcomes including intrauterine growth retardation, premature birth, and spontaneous abortion (reviewed in [152]). The mechanisms that underlie maternofetal tolerance remain incompletely understood but include differential expression of class I HLA molecules [153], altered NK cell activity [154], increased numbers and suppressive activity of regulatory $\mathrm{T}$ cells (Tregs) [155-159], myeloid-derived suppressor cells (MDSCs) [160], high levels of adenosine [2] and progesterone [161, 162], and differences in TLR responses $[45,46]$. Some or all of these mechanisms may impact immune responses during postnatal life and contribute to the vulnerability of neonates and young infants to infection, as well as to vaccine responses that are generally inferior to older children $[1,2,46,61]$. Here we focus on those aspects of immune ontogeny with apparent importance for neonatal HSV infection (Table 1).

5.1. Skin Barrier Function. Differences in epithelial mechanical integrity and production of AMPs may contribute to increased HSV severity in neonates. The epidermis of the fetus and newborn is thinner than that of an adult, predisposing to disruption by trauma [34]. Skin disruption likely increases the risk of neonatal HSV infection, given the association between invasive monitoring (scalp electrodes) and neonatal HSV infection [163]. Other aspects of skin also develop during the neonatal period, including acidification and production of sebum lipids, and might affect HSV infection or replication. Although in theory maternal- and fetalderived AMPs may help prevent HSV infection by blocking entry and replication of virus on mucocutaneous epithelial surfaces, there is no evidence that differences in newborn AMP expression or activity contribute to HSV disease. AMPs such as cathelicidin and lysozyme are abundant in amniotic fluid, vernix caseosa, and newborn epithelia [164-167], and levels of some AMPs appear to be elevated in neonates compared to later in life [35-37]. Nevertheless, identifying and augmenting barrier host defenses may have potential to protect against HSV acquisition or reduce disease severity.

5.2. Autophagy. It is unclear if differences in autophagy in neonatal central neurons relative to older children and adults affect the severity of HSV infection. However, this would not be surprising given rapid growth and development of the brain during this period and the role of autophagy in neurodevelopment [168, 169]. In addition, autophagy can be induced by signaling through several TLRs associated with control of HSV in the nervous system, including TLR2, TLR3, and TLR9 [41, 42]. As discussed later, there are differences between neonates and adults in the effects of TLR signaling on conventional innate immune responses; similar developmental differences may exist with respect to TLR induction of autophagy.

5.3. Pattern Recognition Receptor Mediated Responses. TLR responses change profoundly with age (reviewed in [46]). The expression and function of other PRRs (including RLRs, NLRs, IFI16, etc.) during the neonatal period have not been as well described but are also likely to change during early life [170] and may be important in the pathogenesis of neonatal HSV. The involvement of TLR signaling in protection (TLR3) or pathologic inflammation (TLR2) during HSV CNS disease 
TABLE 1: Immune defenses against HSV with relevance for neonates.

\begin{tabular}{|c|c|c|c|}
\hline Immune defense & Role in controlling HSV infection & $\begin{array}{l}\text { Immunologic differences in } \\
\text { newborns }\end{array}$ & Comments \\
\hline Integument & $\begin{array}{l}\text { The skin and mucosa provide } \\
\text { mechanical and innate antiviral } \\
\text { impediments to HSV infection and } \\
\text { spread. }\end{array}$ & $\begin{array}{l}\text { Neonates have thin, easily } \\
\text { disrupted skin, with differences } \\
\text { in } \mathrm{pH} \text { and sebum production } \\
\text { [34]. }\end{array}$ & $\begin{array}{l}\text { Differences in neonatal epithelial anatomy or } \\
\text { function have not been formally shown to } \\
\text { contribute to susceptibility to HSV infection. } \\
\text { Levels of some AMPs appear to be increased } \\
\text { during the neonatal period [35-37]. }\end{array}$ \\
\hline Autophagy & $\begin{array}{l}\text { HSV-mediated suppression of } \\
\text { autophagy is central to the } \\
\text { pathogenesis of CNS infection } \\
\text { [38-40]. }\end{array}$ & $\begin{array}{l}\text { Autophagy is mediated by } \\
\text { signaling through TLRs, which } \\
\text { have age-dependent responses } \\
{[41,42] \text {. }}\end{array}$ & $\begin{array}{l}\text { Age-dependent differences in autophagy are } \\
\text { plausible but poorly understood. }\end{array}$ \\
\hline PRR responses & $\begin{array}{l}\text { PRR signaling in HSV-infected cells } \\
\text { induces type } 1 \text { IFN production that } \\
\text { limits initial spread of infection } \\
\text { through and attracts and primes } \\
\text { protective Thl-type responses } \\
{[43,44] .}\end{array}$ & $\begin{array}{l}\text { Neonates have qualitatively } \\
\text { different monocyte and DC TLR } \\
\text { responses that result in reduced } \\
\text { type } 1 \text { IFN and IL-12 production, } \\
\text { resulting in weaker Thl-type } \\
\text { responses [45-48]. }\end{array}$ & $\begin{array}{l}\text { Age-dependent TLR } 3 \text { responses to HSV are } \\
\text { likely important based on the association } \\
\text { between CNS HSV infections and defects in } \\
\text { TLR signaling. Age-dependent effects of other } \\
\text { TLR or PRR responses are unclear but may } \\
\text { also be important for the severity of HSV } \\
\text { infection in neonates. }\end{array}$ \\
\hline NK cells & $\begin{array}{l}\text { NK cells are important for control } \\
\text { of initial HSV infection prior to } \\
\text { development of specific T cell } \\
\text { responses [49-51]. }\end{array}$ & $\begin{array}{l}\text { Neonates appear to have } \\
\text { impaired NK cell killing of } \\
\text { HSV-infected cells [52-54]. }\end{array}$ & $\begin{array}{l}\text { Whether neonatal NK cells have any intrinsic } \\
\text { defects or kill less well as a result of impaired } \\
\text { activation, for example, decreased IL-12 } \\
\text { production by DCs, is unclear [55]. }\end{array}$ \\
\hline $\mathrm{T}$ cell responses & $\begin{array}{l}\mathrm{CD} 8^{+} \mathrm{T} \text { cell responses appear } \\
\text { central to control of HSV } \\
\text { replication and prevention of } \\
\text { recurrence }[56,57]\end{array}$ & $\begin{array}{l}\text { Neonatal T cells respond } \\
\text { relatively poorly to HSV [58-60]. }\end{array}$ & $\begin{array}{l}\text { Impaired Thl-type responses against HSV in } \\
\text { neonates may be due to differences in innate } \\
\text { responses by antigen-presenting cells, } \\
\text { intrinsic epigenetic factors (e.g., } \\
\text { hypermethylation of the IFN- } \gamma \text { promoter in } \\
\mathrm{CD}^{+} \text {cells), or perhaps active suppression by } \\
\text { suppressor cells }[2,61,62] \text {. }\end{array}$ \\
\hline Antibody & $\begin{array}{l}\text { HSV neutralizing antibody or } \\
\text { ADCC may protect against } \\
\text { acquisition of infection }[17-21] \text {. }\end{array}$ & $\begin{array}{l}\text { Infants born to women with } \\
\text { established HSV infections } \\
\text { receive virus-specific } \\
\text { transplacental maternal antibody } \\
\text { [4]. }\end{array}$ & $\begin{array}{l}\text { Although infants of women with established } \\
\text { HSV infection are much less likely to become } \\
\text { infected compared to those who acquire } \\
\text { primary infection during pregnancy, no } \\
\text { definitive proof exists that antibody alone is } \\
\text { protective in humans. After infection, } \\
\text { antibody responses do not appear to } \\
\text { contribute significantly to control of HSV } \\
\text { replication. }\end{array}$ \\
\hline
\end{tabular}

suggests the possibility that developmental differences in TLR responses may be involved in the susceptibility of neonates to severe HSV infection. Compared to adults, conventional DCs from cord blood produce significantly less IFN- $\alpha$ and IL-12 upon stimulation with the TLR3 agonist poly(I:C) and show lower expression of CD40 and CD80 [171]. Indeed, IFN$\alpha$ and IL-12p70 (and consequently IFN- $\gamma$ ) responses to most TLR agonists, including $\mathrm{PAM}_{3} \mathrm{CSK}_{4}$ (TLR2/6) and CpGA (TLR9), appear to be relatively weak in conventional and plasmacytoid DCs as well as monocytes from cord blood, while IL-1 $\beta$, IL-6, IL-23, and especially IL-10 responses are as high or often much higher than in adult PBMC [45]. Experiments using neonatal mice found improved control of HSV-1 infection by expanding the number of DCs with Flt-3 ligand (Flt3-L) treatment, which resulted in increased production of IFN- $\alpha / \beta$ and IL-12 [71]. Consistent with these findings, IFN$\alpha$ production in cord blood or neonatal mononuclear cells appears to be reduced in response to in vitro HSV-1 stimulation $[18,172]$. This pattern of a neonatal bias, toward Th2- and Th17-type and away from Th1-type responses, is consistent with impaired control of HSV infection (as well as other intracellular pathogens), and perhaps with increased pathologic inflammation [46]. Interestingly, the ontogeny of individual TLR responses varies. Stimulation of monocytes using TLR3 agonists leads to lower levels of IFN- $\alpha$ when cells isolated from children age 1 or lower are compared with those from adults; however, for TLR9 agonists, comparable responses can be demonstrated within the first few weeks of life $[47,146]$, that is, the same time period during which infants are susceptible to severe HSV infection.

The mechanistic basis for differences in TLR responses in neonates is not well understood [46], but preliminary evidence suggests that both cell-cell interactions and soluble blood factors may be involved [45, 173]. Decreased MyD88 expression in neonatal monocytes $[174,175]$ might explain some of these effects given that this adaptor protein is utilized by all TLRs, with the exception of TLR3. Of note, adult MyD88-deficient mice do not control HSV after corneal 
inoculation and progress to fatal encephalitis [176]. However, MyD88 expression was reported to be equal in purified neonatal and adult pDCs, while reduced type 1 IFN production in neonatal pDCs appeared to be due to impaired nuclear translocation of IRF7 [177]. Decreased IFN- $\beta$ production may be due in part to altered DNA binding of CREB and IRF3 [178]. Developmental differences in nucleosome remodeling and availability of cytokine promoter sites, for example, IL12 p35 $[179,180]$, in neonatal monocytes and antigen-presenting cells may be responsible for some of observed cord blood TLR responses, similar to what has been reported for IFN- $\gamma$ in T cells [181]. Increased levels of adenosine, which increases intracellular cAMP [182], as well as other soluble factors [173] in neonatal blood, also appear to be important for suppressing Th1-polarizing responses.

5.4. Natural Killer Cells. Impaired killing of HSV-infected cells by cord blood mononuclear cells has long been recognized [52-54]. This could result from impaired activation by cytokines such as type 1 IFNs and IL-12, the production of which is reduced in neonates as mentioned earlier, or may reflect intrinsic differences of neonatal NK cells. NK cells in cord blood may differ with respect to the expression of cell surface markers compared to those from the peripheral blood of adults (reviewed in [55]). For example, some studies have found higher levels of the inhibitory receptor complex of CD94/NKG2A and CD158b/j on cord blood NK cells [183, 184]. However, NK cell IFN- $\gamma$ production in response to mitogen appears to be similar between cord blood and adult peripheral blood $[183,185]$. Several studies showed that resting cord blood NK cells are less cytotoxic; however, these cells may actually express higher levels of effector molecules such as perforin and granzyme B $[183,186]$ and can be induced to be highly cytotoxic using stimulation with various combinations of IL-2, IL-12, IL-15, and IL-18 [183, 187-190]. Thus, any impairment in neonatal NK function may represent extrinsic factors, for example, deficient IL-12 production by DCs. The extent to which any NK cell differences in cord blood are relevant to neonatal HSV infection is unknown, but it merits additional study given that NK cells likely play an important role control of HSV infections in general [49, 50, 191, 192].

5.5. Adaptive T Cell Responses. Early studies of neonatal T cell responses to HSV suggested that newborns generate fewer virus-specific cells, which have impaired proliferation to stimulation with virus [58-60]. Furthermore, IFN- $\gamma$ production in response to HSV antigen was significantly lower among neonates and parturient women compared to nonparturient adults, all with recent HSV acquisition [60]. In that study, HSV-specific neonatal IFN- $\gamma$ responses lagged behind those of nonparturient adults until 3-6 weeks after the onset of symptoms. Numerous differences have been described between general responses of neonatal $\mathrm{T}$ cells relative to those of adults $[2,61,62]$. Fetal T cells appear to be derived from a distinct lineage compared to adult $\mathrm{T}$ cells and are biased toward tolerance [193]. Compared to those from adults, neonatal $\mathrm{CD} 4^{+} \mathrm{T}$ lymphocytes are more apt to produce Th2than Th1-type cytokines under the same conditions [194, 195].
Newborn $\mathrm{CD}^{+}$T cells may produce lower levels of IFN- $\gamma$ than adult naïve $\mathrm{T}$ cells due to hypermethylation at $\mathrm{CpG}$ and non-CpG sites within the IFN- $\gamma$ promoter $[181,196]$. Interestingly, neonatal $\mathrm{CD}^{+}{ }^{+} \mathrm{T}$ cells produce similar levels of IFN$\gamma$ and have a pattern of IFN- $\gamma$ promoter methylation comparable to that of naïve adult cells [196]. In addition, neonatal cellular responses may be inhibited by the presence of suppressive soluble factors or suppressor cell populations.

Substantial evidence suggests that regulatory $\mathrm{T}$ cells (Tregs) play a critical role in maternofetal tolerance [155-159]. Studies in mice suggest that Tregs may also differentially suppress neonatal $\mathrm{CD}^{+} \mathrm{T}$ cell responses to HSV compared to adults [197]. Other suppressor cell populations may be involved in neonatal immunity. MDSCs are heterogeneous populations of immature granulocytes or monocytes that suppress $\mathrm{T}$ cell responses and are important in tumor immunology (reviewed in [198-200]). MDSCs appear to prevent inflammation in utero based on studies in mice [160]. Although they are present in peripheral blood in very small numbers in healthy adults, MDSCs are found in high frequencies in pregnant women and cord blood and wane during infancy (Helen Horton, personal communication). MDSCs have been reported to preferentially induce Th-2 responses and impair NK and DC responses (reviewed in [201-203]), all of which are characteristic of neonatal immune responses. However, the extent to which Tregs, MDSC, or other suppressor cells contribute to susceptibility to HSV or other infections during postnatal life requires additional research.

5.6. Antibody. As discussed earlier, virus-specific antibody might prevent HSV acquisition via neutralization or contribute to control of infection through neutralization or ADCC. A large number of observational studies suggest that, though not completely protective, maternal anti-HSV antibody can reduce the risk of neonatal HSV acquisition [17-21]. This is also supported by studies in mouse models showing protection against neonatal HSV infection by virus-specific maternal antibodies [204-206]. High titers of antibody to HSV among infected newborns at presentation have been suggested to result in less severe disease in some studies [18, 207] but not others [208, 209]. Infants typically develop virusspecific IgM within weeks of HSV infection; however, there is no evidence that these responses contribute to control of infection, recurrences, or outcome. This is consistent with the apparent lack of association between humoral immunodeficiencies and severe HSV infections.

\section{Possible Interventions Targeting Host Defenses to Prevent Neonatal HSV}

6.1. Vaccination. Vaccination is considered the intervention with the greatest potential for preventing neonatal HSV [4]. Since acquisition of primary infection during pregnancy confers the highest risk for neonatal HSV disease [163, 210], a prophylactic vaccine would ideally confer high levels of protection against genital HSV in pregnant women. Despite extensive efforts, there are currently no licensed vaccines to 
either prevent HSV acquisition or minimize transmission in humans $[63,211]$. Clinical trials of candidate prophylactic vaccines against HSV-2 have demonstrated limited clinical activity [212-214]; however, these studies have uncovered important information about host immunity to HSV. Randomized trials of a subunit vaccine comprised of the HSV-2 surface glycoproteins $\mathrm{gB}$ and $\mathrm{gD}$ revealed that serum neutralizing antibody levels did not correlate with protection from HSV infection in humans [213], suggesting that additional responses, perhaps mucosal or cellular responses, are also needed to confer sterilizing immunity [215]. Even in the absence of complete protection against HSV infection, a prophylactic vaccine that modified the course of infection, by limiting maternal viral reactivation and genital shedding, could still reduce neonatal disease. Such a vaccine would likely require induction of cellular immune responses to HSV. Indeed, a prior study of therapeutic vaccination of individuals with latent genital HSV-2 infection suggested that recurrences might be diminished in some individuals in a manner that did not correlate with antibody production, supporting the concept that cellular immunity is critical to protecting the mucosa from HSV replication [216]. From this standpoint, recent studies elucidating the mechanism of infiltration of HSV-specific $\mathrm{CD}^{+}{ }^{+} \mathrm{T}$-cells into genital mucosa [121] may provide insight into novel vaccination strategies, such as the "prime-pull" strategy suggested by Shin and Iwasaki [217].

Alternative approaches to improve vaccine responses have aimed to enhance immunogenicity. Among those showing preclinical promise in animal models are novel delivery systems such as liposomes [218], modified recombinant bacteria expressing HSV antigens [219], and incorporating the use of novel adjuvants [220] or DNA vaccines [221, 222]. One possible limitation of these approaches is their reliance on a single or a limited set of viral antigens (typically gD, often with 1-2 additional targets) to provide protection against a virus with a genome that encodes more than 80 proteins. Broader antiviral responses could be generated with attenuated or replication-defective viral vectors [215, 223, 224], which in some instances have demonstrated protection in animal models [225-228]. However, it is not clear whether some of these alterations of the virus may remove important targets of human immunity. Other modifications to the viral genome, such as inserting a dominant-negative mutant gene [229] or inserting costimulatory genes [230, 231], may carry the risk of gene transfer to a wild-type virus through heterologous recombination [232]. Novel delivery systems or adjuvants need to be produced in a cost-effective manner, require careful evaluation for safety in humans, and may promote unacceptable inflammatory responses [233].

6.2. Other Immunologic Strategies to Prevent HSV Infection. Biological products based on immune proteins, such as cationic AMPs, have been proposed as potential candidates to protect against HSV infection [93, 234, 235]. These molecules might be formulated as microbicides, for example, to prevent maternal acquisition of HSV, or transmission to the infant during birth [64].

\section{Possible Interventions to Modulate the Immune Response to Neonatal HSV Infection}

Alternative approaches to modify host immunity for treatment of neonatal HSV infection have been suggested (Table 2). These strategies have hypothetical benefits that merit study but should not be considered for clinical use until safety and efficacy have been established.

7.1. Suppression of Local Inflammatory Response in the CNS. As discussed earlier, data from animal models suggest that deleterious inflammatory responses may play an important role in the pathogenesis of HSV encephalitis [65-67]. Numerous cases of HSV encephalitis treatment using adjunctive corticosteroids with good outcomes, mostly in adults, have been reported [68-70]; however, given the risk of increased viral replication and cytotoxic effects, this approach is controversial [236, 237]. In order to develop targeted immunomodulatory therapies for neonatal HSV infection, a better understanding is needed of the relative contributions and temporal dynamics of the specific inflammatory pathways that mediate control of viral replication and immune-mediated CNS damage [238].

7.2. Targeting Autophagy. Development of novel antivirals has been proposed to target HSV proteins that inhibit autophagy [76], and early studies suggest that agents that induce autophagy can inhibit HSV replication [77, 78].

7.3. Promotion of Th1-Type Responses. Strategies can also be envisioned that promote Th1-type responses during the neonatal period through novel adjuvants like TLR agonists [47, 48], growth factors such as Flt3-L [71], or other agents that target antigen-presenting cells. If suppressor cell populations are confirmed to impair neonatal immune responses, interventions to oppose the effects of these cells might result in Th1-type responses to HSV more similar to those produced by adults. In models of other diseases, such as HIV infection and melanoma, therapies have been proposed to reverse Treg activity and enhance protective $\mathrm{T}$ cell responses, for example, with recombinant IL-7 or blockade of negative costimulatory receptors CTLA-4 and PD-1 [72, 73]. Similarly, studies in solid tumor patients have shown that the suppressive activity of MDSC can be reversed by 25-hydroxyvitamin $\mathrm{D}_{3}$, alltrans-retinoic acid, and other therapies [74]. Any of these immunomodulatory strategies might be expected to improve neonatal responses not just to HSV, but also other neonatal pathogens and vaccines, as well as to potentially prevent atopic diseases [48]. It should be stressed again that any benefit of these interventions for neonatal HSV infection is currently entirely theoretical, and their use for any indication requires extensive study to assure safety in newborns. 
TABle 2: Potential interventions targeting host defenses against neonatal HSV infection.

\begin{tabular}{ll}
\hline Potential intervention & Comments \\
\hline Maternal vaccination & $\begin{array}{l}\text { No effective HSV vaccine is yet available. Neonatal HSV infection could be prevented by a vaccine that } \\
\text { either conferred sterilizing immunity to women prior to pregnancy and/or by modifying infection in } \\
\text { women to reduce viral replication and shedding in the genital mucosa [63]. }\end{array}$ \\
\hline Antimicrobial peptides & $\begin{array}{l}\text { AMPs formulated as a vaginal microbicide might prevent HSV infection during pregnancy and/or reduce } \\
\text { intrapartum transmission [64]. }\end{array}$ \\
\hline $\begin{array}{l}\text { Immunosuppressive } \\
\text { therapy for CNS infection }\end{array}$ & $\begin{array}{l}\text { Some component of the immune response to HSV encephalitis may result in pathologic inflammation and } \\
\text { contribute to poor outcomes [65-67]. Despite case reports of good outcomes using adjunctive } \\
\text { corticosteroids in adults or neonates with HSV CNS infection [68-70], no controlled studies have been } \\
\text { performed and this or other immunosuppressive treatments cannot currently be recommended given the } \\
\text { risks of increased viral replication and cytotoxic effects. }\end{array}$ \\
\hline $\begin{array}{l}\text { Immunomodulation of } \\
\text { neonatal Th2/Th17 bias }\end{array}$ & $\begin{array}{l}\text { Thl-type responses might be promoted during the neonatal period with novel adjuvants such as } \\
\text { imazoquinolines [47, 48], growth factors such as Flt3-L [71], or other agents that target antigen-presenting } \\
\text { cells. These strategies might conceivably be used therapeutically during infection or to prime all neonates } \\
\text { to respond to infection and vaccinations [48]. }\end{array}$ \\
\hline $\begin{array}{l}\text { Inhibition of suppressor } \\
\text { cell function }\end{array}$ & $\begin{array}{l}\text { Tregs, MDSCs, or other suppressor cell populations might contribute to impaired T cell responses during } \\
\text { early infancy. Modulation of these cells' activity might improve immunity to HSV infection, such as what } \\
\text { has been proposed for HIV and cancer [72-74]. Inhibition of suppressor cell function during HSV } \\
\text { infection might also result in uncontrolled inflammation and worse outcomes [75]. }\end{array}$ \\
\hline $\begin{array}{l}\text { Induction of autophagy } \\
\text { sovel antivirals have been proposed to target HSV virulence factors that inhibit autophagy [76], and early } \\
\text { pentagalloylglucose both induce autophagy and inhibit HSV replication in vitro [77, 78]. }\end{array}$ \\
\hline
\end{tabular}

\section{Conclusions and Directions for Future Research}

An effective prophylactic HSV vaccine represents an ideal way to prevent neonatal HSV infection. In the absence of such a vaccine, early recognition and aggressive antiviral treatment of neonatal HSV infection remain the mainstays of care. The development of new interventions for neonatal HSV discussed earlier requires a better understanding of the mechanistic basis of immune control of HSV infection in general and how neonatal responses to HSV are ineffective by comparison. Specifically, more studies are required to understand the basis of differential TLR and other pattern recognition receptor responses in early life and their effects on neonatal HSV infection. Differences in T cell responses to HSV between neonates and older children or adults also merit more study, as do the relative contributions of impaired priming, inherent differences in $\mathrm{T}$ cell signaling, and/or active suppression on poor cellular control of HSV infection during the newborn period. The role of Tregs, MDSC, and other suppressor cell populations in immune control of HSV infection is also of great interest. More complete knowledge of immune ontogeny could lead to interventions that might be routinely given to all newborns to improve immune responses not just to HSV, but to a wide range of other infectious pathogens and vaccines as well.

Just as important as understanding the immunology of how neonates differ from older children and adults, however, is to determine what benefits if any there are during early postnatal life that come from the apparent persistence of in utero tolerance. If immune response patterns in early infancy simply represent a transition between fetal and adult-type immune responses that requires time but serves no function, it may be safe and advantageous to expedite this process. It is possible, however, that the ontogeny of immune system during early postnatal life is evolutionarily adaptive. It has been hypothesized that without relative tolerance immediately postpartum, rapid colonization of newborns with myriad microorganisms and non-self-antigens might lead to overwhelming inflammation [2]. Other possibilities, which are not mutually exclusive, include the possibility that relative neonatal tolerance protects against autoimmunity and allergies [170, 239]. Neonatal HSV infection represents both an important clinical problem and a fascinating example of age-dependent immunity. Through a greater understanding of the dynamic interplay between the virus and host, there are opportunities to rationally develop safe and effective therapies to prevent or treat neonatal HSV infection.

\section{Acknowledgment}

The authors thank Dr. Lisa Frenkel for reviewing the paper.

\section{References}

[1] C. Wilson and T. Kollmann, "Induction of antigen-specific immunity in human neonates and infants," Nestle Nutrition Workshop Series, vol. 61, pp. 183-195, 2008.

[2] O. Levy, "Innate immunity of the newborn: basic mechanisms and clinical correlates," Nature Reviews Immunology, vol. 7, no. 5, pp. 379-390, 2007.

[3] S. Ygberg and A. Nilsson, "The developing immune systemfrom foetus to toddler," Acta Paediatrica, vol. 101, pp. 120-127, 2012. 
[4] L. Corey and A. Wald, "Maternal and neonatal herpes simplex virus infections," The New England Journal of Medicine, vol. 361, no. 14, pp. 1376-1385, 2009.

[5] P. E. Pellett and B. Roizman, "The family herpesviridae: a brief introduction," in Fields Virology, D. M. Knipe and P. M. Howley, Eds., pp. 2479-2499, Lippincott, Williams, \& Wilkins, Philadelphia, Pa, USA, 2007.

[6] J. I. Cohen, "Introduction to Herpesviridae," in Mandell, Douglas, and Bennett's Principles and Practice of Infectious Diseases, G. L. Mandell, J. E. Bennett, and R. Dolin, Eds., pp. 19371942, Churchill-Livingstone Elsevier, Philadelphia, Pa, USA, 7th edition, 2009.

[7] L. Corey and P. G. Spear, "Infections with herpes simplex viruses," The New England Journal of Medicine, vol. 314, no. 12, pp. 749-757, 1986.

[8] J. T. Schiffer and L. Corey, "New concepts in understanding genital herpes," Current Infectious Disease Reports, vol. 11, no. 6, pp. 457-464, 2009.

[9] D. L. Schmitt, D. W. Johnson, and F. W. Henderson, "Herpes simplex type 1 infections in group day care," Pediatric Infectious Disease Journal, vol. 10, no. 10, pp. 729-734, 1991.

[10] A. G. M. Langenberg, L. Corey, R. L. Ashley, W. P. Leong, and S. E. Straus, "A prospective study of new infections with herpes simplex virus type 1 and type 2," The New England Journal of Medicine, vol. 341, no. 19, pp. 1432-1438, 1999.

[11] S. L. Sacks, P. D. Griffiths, L. Corey et al., "HSV shedding," Antiviral Research, vol. 63, supplement 1, pp. S19-S26, 2004.

[12] A. Wald, J. Zeh, S. Selke et al., "Reactivation of genital herpes simplex virus type 2 infection in asymptomatic seropositive persons," The New England Journal of Medicine, vol. 342, no. 12, pp. 844-850, 2000.

[13] D. M. Koelle, J. Benedetti, A. Langenberg, and L. Corey, "Asymptomatic reactivation of herpes simplex virus in women after the first episode of genital herpes," Annals of Internal Medicine, vol. 116, no. 6, pp. 433-437, 1992.

[14] K. E. Mark, A. Wald, A. S. Magaret et al., "Rapidly cleared episodes of herpes simplex virus reactivation in immunocompetent adults," Journal of Infectious Diseases, vol. 198, no. 8, pp. 1141-1149, 2008.

[15] F. Xu, M. R. Sternberg, B. J. Kottiri et al., "Trends in herpes simplex virus type 1 and type 2 seroprevalence in the United States," Journal of the American Medical Association, vol. 296, no. 8, pp. 964-973, 2006.

[16] J. T. Schiffer and L. Corey, "Herpes simplex virus," in Mandell, Douglas, and Bennett's Principles and Practice of Infectious Diseases, G. L. Mandell, J. E. Bennett, and R. Dolin, Eds., Churchill Livingstone, Philadelphia, Pa, USA, 7th edition, 2009.

[17] C. G. Prober, W. M. Sullender, and L. L. Yasukawa, "Low risk herpes simplex virus infections in neonates exposed to the virus at the time of vaginal delivery to mothers with recurrent genital herpes simplex virus infections," The New England Journal of Medicine, vol. 316, no. 5, pp. 240-244, 1987.

[18] W. M. Sullender, J. L. Miller, and L. L. Yasukawa, "Humoral and cell-mediated immunity in neonates with herpes simplex virus infection," Journal of Infectious Diseases, vol. 155, no. 1, pp. 28-37, 1987.

[19] Z. A. Brown, S. Selke, J. Zeh et al., "The acquisition of herpes simplex virus during pregnancy," The New England Journal of Medicine, vol. 337, no. 8, pp. 509-515, 1997.

[20] E. L. Brown, R. Morrow, E. M. Krantz et al., "Maternal herpes simplex virus antibody avidity and risk of neonatal herpes,"
American Journal of Obstetrics and Gynecology, vol. 195, no. 1, pp. 115-120, 2006.

[21] R. L. Ashley, J. Dalessio, S. Burchett et al., "Herpes simplex virus-2 (HSV-2) type-specific antibody correlates of protection in infants exposed to HSV-2 at birth," Journal of Clinical Investigation, vol. 90, no. 2, pp. 511-514, 1992.

[22] O. Kortekangas-Savolainen and T. Vuorinen, "Trends in herpes simplex virus type 1 and 2 infections among patients diagnosed with genital herpes in a Finnish sexually transmitted disease clinic, 1994-2002," Sexually Transmitted Diseases, vol. 34, no. 1, pp. 37-40, 2007.

[23] P. Bhattarakosol, S. Visaprom, A. Sangdara, and V. Mungmee, "Increase of genital HSV-1 and mixed HSV-1 and HSV-2 infection in Bangkok, Thailand," Journal of the Medical Association of Thailand, vol. 88, pp. S300-S304, 2005.

[24] L. J. Haddow, B. Dave, A. Mindel et al., "Increase in rates of herpes simplex virus type 1 as a cause of anogenital herpes in western Sydney, Australia, between 1979 and 2003," Sexually Transmitted Infections, vol. 82, no. 3, pp. 255-259, 2006.

[25] T. Tran, J. D. Druce, M. C. Catton, H. Kelly, and C. J. Birch, "Changing epidemiology of genital herpes simplex virus infection in Melbourne, Australia, between 1980 and 2003," Sexually Transmitted Infections, vol. 80, no. 4, pp. 277-279, 2004.

[26] K. Manavi, A. McMillan, and M. Ogilvie, "Herpes simplex virus type 1 remains the principal cause of initial anogenital herpes in edinburgh, Scotland," Sexually Transmitted Diseases, vol. 31, no. 5, pp. 322-324, 2004.

[27] R. Horowitz, S. Aierstuck, E. A. Williams, and B. Melby, "Herpes simplex virus infection in a university health population: clinical manifestations, epidemiology, and implications," Journal of American College Health, vol. 59, no. 2, pp. 69-74, 2010.

[28] V. S. Pereira, R. N. Moizeis, T. A. Fernandes, J. M. Araujo, R. V. Meissner et al., "Herpes simplex virus type 1 is the main cause of genital herpes in women of Natal, Brazil," European Journal of Obstetrics, Gynecology, and Reproductive Biology, vol. 161, pp. 190-193, 2012.

[29] D. I. Bernstein, A. R. Bellamy, E. W. Hook, M. J. Levin, A. Wald et al., "Epidemiology, clinical presentation and antibody response to primary infection with herpes simplex virus type 1 and type 2 in young women," Clinical Infectious Diseases, vol. 56, no. 3, pp. 344-351, 2013.

[30] R. Gupta, T. Warren, and A. Wald, "Genital herpes," The Lancet, vol. 370, no. 9605, pp. 2127-2137, 2007.

[31] W. C. Reeves, L. Corey, and H. G. Adams, "Risk of recurrence after first episodes of genital herpes. Relation to HSV type and antibody response," The New England Journal of Medicine, vol. 305, no. 6, pp. 315-319, 1981.

[32] L. Corey, A. Mindel, and K. H. Fife, "Risk of recurrence after treatment of first-episode genital herpes with intravenous acyclovir," Sexually Transmitted Diseases, vol. 12, no. 4, pp. 215$218,1985$.

[33] A. Mindel, I. V. D. Weller, and A. Faherty, "Acyclovir in first attacks of genital herpes and prevention of recurrences," Genitourinary Medicine, vol. 62, no. 1, pp. 28-32, 1986.

[34] J. W. Fluhr, R. Darlenski, A. Taieb et al., "Functional skin adaptation in infancy-almost complete but not fully competent," Experimental Dermatology, vol. 19, no. 6, pp. 483-492, 2010.

[35] V. P. Walker, H. T. Akinbi, J. Meinzen-Derr, V. Narendran, M. Visscher, and S. B. Hoath, "Host defense proteins on the surface of neonatal skin: implications for innate immunity," Journal of Pediatrics, vol. 152, no. 6, pp. 777-781, 2008. 
[36] R. A. Dorschner, K. H. Lin, M. Murakami, and R. L. Gallo, "Neonatal skin in mice and humans expresses increased levels of antimicrobial peptides: innate immunity during development of the adaptive response," Pediatric Research, vol. 53, no. 4, pp. 566-572, 2003.

[37] M. Murakami, T. Ohtake, R. A. Dorschner, and R. L. Gallo, "Cathelicidin antimicrobial peptides are expressed in salivary glands and saliva," Journal of Dental Research, vol. 81, no. 12, pp. 845-850, 2002.

[38] A. Orvedahl and B. Levine, "Autophagy and viral neurovirulence," Cellular Microbiology, vol. 10, no. 9, pp. 1747-1756, 2008.

[39] A. Orvedahl, D. Alexander, Z. Tallóczy et al., "HSV-1 ICP34.5 confers neurovirulence by targeting the beclin 1 autophagy protein," Cell Host and Microbe, vol. 1, no. 1, pp. 23-35, 2007.

[40] M. Lussignol, C. Queval, M. F. Bernet-Camard, J. Cotte-Laffitte, I. Beau et al., "The herpes simplex virus type 1 Us11 protein inhibits autophagy through its interaction with the protein kinase PKR," Journal of Virology, vol. 87, pp. 859-871, 2013.

[41] C. S. Shi and J. H. Kehrl, "MyD88 and Trif target Beclin 1 to trigger autophagy in macrophages," Journal of Biological Chemistry, vol. 283, no. 48, pp. 33175-33182, 2008.

[42] M. A. Delgado and V. Deretic, "Toll-like receptors in control of immunological autophagy," Cell Death and Differentiation, vol. 16, no. 7, pp. 976-983, 2009.

[43] J. Melchjorsen, "Sensing herpes: more than toll," Reviews in Medical Virology, vol. 22, pp. 106-121, 2012.

[44] N. Martinez-Martin and A. Viejo-Borbolla, "Toll-like receptormediated recognition of herpes simplex virus," Frontiers in Bioscience, vol. 2, pp. 718-729, 2010.

[45] T. R. Kollmann, J. Crabtree, A. Rein-Weston et al., "Neonatal innate TLR-mediated responses are distinct from those of adults," Journal of Immunology, vol. 183, no. 11, pp. 7150-7160, 2009.

[46] T. R. Kollmann, O. Levy, R. R. Montgomery, and S. Goriely, "Innate immune function by toll-like receptors: distinct responses in newborns and the elderly," Immunity, vol. 37, pp. 771783, 2012.

[47] O. Levy, S. Goriely, and T. R. Kollmann, "Immune response to vaccine adjuvants during the first year of life," Vaccine, 2012.

[48] S. C. Diesner, E. Forster-Waldl, A. Olivera, A. Pollak, E. JensenJarolim et al., "Perspectives on immunomodulation early in life," Pediatric Allergy and Immunology, vol. 23, pp. 210-223, 2012.

[49] S. Jawahar, C. Moody, M. Chan, R. Finberg, R. Geha, and T. Chatila, "Natural killer (NK) cell deficiency associated with an epitope-deficient Fc receptor type IIIA (CD16-II)," Clinical and Experimental Immunology, vol. 103, no. 3, pp. 408-413, 1996.

[50] C. A. Biron, K. S. Byron, and J. L. Sullivan, "Severe herpesvirus infections in an adolescent without natural killer cells," The New England Journal of Medicine, vol. 320, no. 26, pp. 1731-1735, 1989.

[51] S. E. Chisholm, K. Howard, M. V. Gómez, and H. T. Reyburn, "Expression of ICP0 is sufficient to trigger natural killer cell recognition of herpes simplex virus-infected cells by natural cytotoxicity receptors," Journal of Infectious Diseases, vol. 195, no. 8, pp. 1160-1168, 2007.

[52] S. Kohl, L. S. Loo, and B. Gonik, "Analysis in human neonates of defective antibody-dependent cellular cytotoxicity and natural killer cytotoxicity to herpes simplex virus-infected cells," Journal of Infectious Diseases, vol. 150, no. 1, pp. 14-19, 1984.

[53] S. Kohl, M. S. West, and L. S. Loo, "Defects in interleukin2 stimulation of neonatal killer cytotoxicity to herpes simplex virus-infected cells," Journal of Pediatrics, vol. 112, no. 6, pp. 976981, 1988.
[54] J. P. Frazier, S. Kohl, L. K. Pickering, and L. S. Loo, "The effect of route of delivery on neonatal natural killer cytotoxicity and antibody-dependent cellular cytotoxicity to herpes simplex virus-infected cells," Pediatric Research, vol. 16, no. 7, pp. 558560, 1982.

[55] M. R. Verneris and J. S. Miller, "The phenotypic and functional characteristics of umbilical cord blood and peripheral blood natural killer cells," British Journal of Haematology, vol. 147, no. 2, pp. 185-191, 2009.

[56] J. Zhu, D. M. Koelle, J. Cao et al., "Virus-specific $\mathrm{CD}^{+} \mathrm{T}$ cells accumulate near sensory nerve endings in genital skin during subclinical HSV-2 reactivation," Journal of Experimental Medicine, vol. 204, no. 3, pp. 595-603, 2007.

[57] J. T. Schiffer, L. Abu-Raddad, K. E. Mark et al., "Mucosal host immune response predicts the severity and duration of herpes simplex virus-2 genital tract shedding episodes," Proceedings of the National Academy of Sciences of the United States of America, vol. 107, no. 44, pp. 18973-18978, 2010.

[58] R. F. Pass, M. E. Dworsky, and R. J. Whitley, "Specific lymphocyte blastogenic responses in children with cytomegalovirus and herpes simplex virus infections acquired early in infancy," Infection and Immunity, vol. 34, no. 1, pp. 166-170, 1981.

[59] A. R. Hayward, M. J. Herberger, J. Groothuis, and M. R. Levin, "Specific immunity after congenital or neonatal infection with cytomegalovirus or herpes simplex virus," Journal of Immunology, vol. 133, no. 5, pp. 2469-2473, 1984.

[60] S. K. Burchett, L. Corey, K. M. Mohan, J. Westall, R. Ashley, and C. B. Wilson, "Diminished interferon- $\gamma$ and lymphocyte proliferation in neonatal and postpartum primary herpes simplex virus infection," Journal of Infectious Diseases, vol. 165, no. 5, pp. 813-818, 1992.

[61] C. A. Siegrist, "Neonatal and early life vaccinology," Vaccine, vol. 19, no. 25-26, pp. 3331-3346, 2001.

[62] A. Marchant and M. Goldman, "T cell-mediated immune responses in human newborns: ready to learn?" Clinical and Experimental Immunology, vol. 141, no. 1, pp. 10-18, 2005.

[63] C. Johnston, D. M. Koelle, and A. Wald, "HSV-2: in pursuit of a vaccine," The Journal of Clinical Investigation, vol. 121, pp. 46004609, 2011.

[64] S. S. Wilson, E. Fakioglu, and B. C. Herold, "Novel approaches in fighting herpes simplex virus infections," Expert Review of Anti-Infective Therapy, vol. 7, no. 5, pp. 559-568, 2009.

[65] P. Lundberg, C. Ramakrishna, J. Brown et al., "The immune response to herpes simplex virus type 1 infection in susceptible mice is a major cause of central nervous system pathology resulting in fatal encephalitis," Journal of Virology, vol. 82, no. 14, pp. 7078-7088, 2008.

[66] C. Ramakrishna, A. N. S. Newo, Y. W. Shen, and E. Cantin, "Passively administered pooled human immunoglobulins exert il-10 dependent anti-inflammatory effects that protect against fatal HSV encephalitis," PLoS Pathogens, vol. 7, no. 6, Article ID e1002071, 2011.

[67] S. J. Kopp, A. H. Karaba, L. K. Cohen, G. Banisadr, R. J. Miller et al., "Pathogenesis of neonatal herpes simplex 2 disease in a mouse model is dependent on entry receptor expression and route of inoculation," Journal of Virology, vol. 87, pp. 474-481, 2013.

[68] M. T. Fitch and D. van de Beek, "Drug Insight: steroids in CNS infectious diseases-new indications for an old therapy," Nature Clinical Practice Neurology, vol. 4, no. 2, pp. 97-104, 2008. 
[69] T. Nagamori, S. Koyano, Y. Asai, F. Nohara, T. Okamoto et al., "Sequential changes in pathophysiology of systemic inflammatory response in a disseminated neonatal herpes simplex virus (HSV) infection," Journal of Clinical Virology, vol. 53, pp. 265267, 2012.

[70] S. Kamei, T. Sekizawa, H. Shiota et al., "Evaluation of combination therapy using aciclovir and corticosteroid in adult patients with herpes simplex virus encephalitis," Journal of Neurology, Neurosurgery and Psychiatry, vol. 76, no. 11, pp. 1544-1549, 2005.

[71] S. Vollstedt, M. Franchini, H. P. Hefti et al., "Flt3 ligandtreated neonatal mice have increased innate immunity against intracellular pathogens and efficiently control virus infections," Journal of Experimental Medicine, vol. 197, no. 5, pp. 575-584, 2003.

[72] M. A. Jenabian, P. Ancuta, N. Gilmore, and J. P. Routy, "Regulatory T cells in HIV infection: can immunotherapy regulate the regulator?" Clinical \& Developmental Immunology, vol. 2012, Article ID 908314, 12 pages, 2012.

[73] M. A. Curran, W. Montalvo, H. Yagita, and J. P. Allison, "PD1 and CTLA- 4 combination blockade expands infiltrating $\mathrm{T}$ cells and reduces regulatory $\mathrm{T}$ and myeloid cells within B16 melanoma tumors," Proceedings of the National Academy of Sciences of the United States of America, vol. 107, no. 9, pp. 42754280, 2010.

[74] A. J. Montero, C. M. Diaz-Montero, C. E. Kyriakopoulos, V. Bronte, and S. Mandruzzato, "Myeloid-derived suppressor cells in cancer patients: a clinical perspective," Journal of Immunotherapy, vol. 35, pp. 107-115, 2012.

[75] J. M. Lund, L. Hsing, T. T. Pham, and A. Y. Rudensky, "Coordination of early protective immunity to viral infection by regulatory T cells," Science, vol. 320, no. 5880, pp. 1220-1224, 2008.

[76] D. C. Rubinsztein, P. Codogno, and B. Levine, "Autophagy modulation as a potential therapeutic target for diverse diseases," Nature Reviews Drug Discovery, vol. 11, pp. 709-730, 2012.

[77] S. Gantt, J. Carlsson, M. Ikoma et al., "The HIV protease inhibitor nelfinavir inhibits Kaposi's sarcoma-associated herpesvirus replication in vitro," Antimicrobial Agents and Chemotherapy, vol. 55, no. 6, pp. 2696-2703, 2011.

[78] Y. Pei, Z. P. Chen, H. Q. Ju et al., "Autophagy is involved in anti-viral activity of pentagalloylglucose (PGG) against Herpes simplex virus type 1 infection in vitro," Biochemical and Biophysical Research Communications, vol. 405, no. 2, pp. 186-191, 2011.

[79] G. T. Vasileiadis, H. W. Roukema, W. Romano, J. C. Walton, and R. Gagnon, "Intrauterine herpes simplex infection," American Journal of Perinatology, vol. 20, no. 2, pp. 55-58, 2003.

[80] C. Hutto, A. Arvin, and R. Jacobs, "Intrauterine herpes simplex virus infections," Journal of Pediatrics, vol. 110, no. 1, pp. 97-101, 1987.

[81] D. W. Kimberlin, "Neonatal herpes simplex infection," Clinical Microbiology Reviews, vol. 17, no. 1, pp. 1-13, 2004.

[82] W. J. Muller, C. A. Jones, and D. M. Koelle, "Immunobiology of herpes simplex virus and cytomegalovirus infections of the fetus and newborn," Current Immunology Reviews, vol. 6, no. 1, pp. 38-55, 2010.

[83] C. Johnston, A. Magaret, S. Selke, M. Remington, L. Corey, and A. Wald, "Herpes simplex virus viremia during primary genital infection," Journal of Infectious Diseases, vol. 198, no. 1, pp. 31-34, 2008.
[84] A. H. Kang and C. R. Graves, "Herpes simplex hepatitis in pregnancy: a case report and review of the literature," Obstetrical and Gynecological Survey, vol. 54, no. 7, pp. 463-468, 1999.

[85] L. Pereira, E. Maidji, S. McDonagh, O. Genbacev, and S. Fisher, "Human cytomegalovirus transmission from the uterus to the placenta correlates with the presence of pathogenic bacteria and maternal immunity," Journal of Virology, vol. 77, no. 24, pp. 13301-13314, 2003.

[86] S. McDonagh, E. Maidji, W. Ma, H. T. Chang, S. Fisher, and L. Pereira, "Viral and bacterial pathogens at the maternal-fetal interface," Journal of Infectious Diseases, vol. 190, no. 4, pp. 826834, 2004.

[87] D. W. Kimberlin, "Herpes simplex virus infections of the newborn," Seminars in Perinatology, vol. 31, no. 1, pp. 19-25, 2007.

[88] D. W. Kimberlin, C. Y. Lin, R. F. Jacobs et al., "Natural history of neonatal herpes simplex virus infections in the acyclovir era," Pediatrics, vol. 108, no. 2, pp. 223-229, 2001.

[89] R. Whitley, A. Arvin, C. Prober et al., "Predictors of morbidity and mortality in neonates with herpes simplex virus infections," The New England Journal of Medicine, vol. 324, no. 7, pp. 450454, 1991.

[90] L. Corey, E. F. Stone, R. J. Whitley, and K. Mohan, "Differrence between herpes simplex virus type 1 and type 2 neonatal encephalitis in neurological outcome," The Lancet, vol. 1, no. 85758576, pp. 1-4, 1988.

[91] D. W. Kimberlin, C. Y. Lin, R. F. Jacobs et al., "Safety and efficacy of high-dose intravenous acyclovir in the management of neonatal herpes simplex virus infections," Pediatrics, vol. 108, no. 2, pp. 230-238, 2001.

[92] D. W. Kimberlin, R. J. Whitley, W. Wan, D. A. Powell, G. Storch et al., "Oral acyclovir suppression and neurodevelopment after neonatal herpes," The New England Journal of Medicine, vol. 365, pp. 1284-1292, 2011.

[93] H. Jenssen, "Therapeutic approaches using host defence peptides to tackle herpes virus infections," Viruses, vol. 1, pp. 939964, 2009.

[94] J. Melchjorsen, S. Matikainen, and S. R. Paludan, "Activation and evasion of innate antiviral immunity by herpes simplex virus," Viruses, vol. 1, pp. 737-759, 2009.

[95] R. J. Duerst and L. A. Morrison, "Innate immunity to herpes simplex virus type 2," Viral Immunology, vol. 16, no. 4, pp. 475490, 2003.

[96] K. L. Mossman and A. A. Ashkar, "Herpesviruses and the innate immune response," Viral Immunology, vol. 18, no. 2, pp. 267-281, 2005.

[97] D. M. Koelle and L. Corey, "Recent progress in herpes simplex virus immunobiology and vaccine research," Clinical Microbiology Reviews, vol. 16, no. 1, pp. 96-113, 2003.

[98] K. M. Khanna, A. J. Lepisto, V. Decman, and R. L. Hendricks, "Immune control of herpes simplex virus during latency," Current Opinion in Immunology, vol. 16, no. 4, pp. 463-469, 2004.

[99] S. Kohl, "Role of antibody-dependent cellular cytotoxicity in neonatal infection with herpes simplex virus," Reviews of Infectious Diseases, vol. 13, supplement 11, pp. S950-S952, 1991.

[100] P. Y. Ong, T. Ohtake, C. Brandt et al., "Endogenous antimicrobial peptides and skin infections in atopic dermatitis," The New England Journal of Medicine, vol. 347, no. 15, pp. 1151-1160, 2002.

[101] A. Wollenberg, S. Wetzel, W. H. C. Burgdorf, and J. Haas, "Viral infections in atopic dermatitis: pathogenic aspects and clinical management," Journal of Allergy and Clinical Immunology, vol. 112, no. 4, pp. 667-674, 2003. 
[102] M. Herman, M. Ciancanelli, Y. H. Ou, L. Lorenzo, M. KlaudelDreszler et al., "Heterozygous TBK1 mutations impair TLR3 immunity and underlie herpes simplex encephalitis of childhood," Journal of Experimental Medicine, vol. 209, pp. 1567-1582, 2012.

[103] A. Casrouge, S. Y. Zhang, C. Eidenschenk et al., "Herpes simplex virus encephalitis in human UNC-93B deficiency," Science, vol. 314, no. 5797, pp. 308-312, 2006.

[104] R. Pérez de Diego, V. Sancho-Shimizu, L. Lorenzo et al., "Human TRAF3 adaptor molecule deficiency leads to impaired toll-like receptor 3 response and susceptibility to herpes simplex encephalitis," Immunity, vol. 33, no. 3, pp. 400-411, 2010.

[105] V. Sancho-Shimizu, R. Perez de Diego, L. Lorenzo, R. Halwani, A. Alangari et al., "Herpes simplex encephalitis in children with autosomal recessive and dominant TRIF deficiency," The Journal of Clinical Investigation, vol. 121, pp. 4889-4902, 2011.

[106] S. Y. Zhang, E. Jouanguy, S. Ugolini et al., "TLR3 deficiency in patients with herpes simplex encephalitis," Science, vol. 317, no. 5844, pp. 1522-1527, 2007.

[107] Y. Guo, M. Audry, M. Ciancanelli, L. Alsina, J. Azevedo et al., "Herpes simplex virus encephalitis in a patient with complete TLR3 deficiency: TLR3 is otherwise redundant in protective immunity," The Journal of Experimental Medicine, vol. 208, pp. 2083-2098, 2011.

[108] S. Dupuis, E. Jouanguy, S. Al-Hajjar et al., "Impaired response to interferon- $\alpha / \beta$ and lethal viral disease in human STAT1 deficiency," Nature Genetics, vol. 33, no. 3, pp. 388-391, 2003.

[109] Y. Minegishi, M. Saito, T. Morio et al., "Human tyrosine kinase 2 deficiency reveals its requisite roles in multiple cytokine signals involved in innate and acquired immunity," Immunity, vol. 25, no. 5, pp. 745-755, 2006.

[110] T. Niehues, J. Reichenbach, J. Neubert et al., "Nuclear factor $\kappa \mathrm{B}$ essential modulator-deficient child with immunodeficiency yet without anhidrotic ectodermal dysplasia," Journal of Allergy and Clinical Immunology, vol. 114, no. 6, pp. 1456-1462, 2004.

[111] Q. Zhang, J. C. Davis, I. T. Lamborn et al., "Combined immunodeficiency associated with DOCK8 mutations," The New England Journal of Medicine, vol. 361, no. 21, pp. 2046-2055, 2009.

[112] L. Abbo, V. Vincek, G. Dickinson, N. Shrestha, S. Doblecki, and P. A. Haslett, "Selective defect in plasmacyoid dendritic cell function in a patient with AIDS-associated atypical genital herpes simplex vegetans treated with imiquimod," Clinical Infectious Diseases, vol. 44, no. 3, pp. e25-e27, 2007.

[113] A. Dalloul, E. Oksenhendler, O. Chosidow et al., "Severe herpes virus (HSV-2) infection in two patients with myelodysplasia and undetectable NK cells and plasmacytoid dendritic cells in the blood," Journal of Clinical Virology, vol. 30, no. 4, pp. 329336, 2004.

[114] G. Pollara, K. Speidel, L. Samady et al., "Herpes simplex virus infection of dendritic cells: balance among activation, inhibition, and immunity," Journal of Infectious Diseases, vol. 187, no. 2, pp. 165-178, 2003.

[115] X. Zhao, E. Deak, K. Soderberg et al., "Vaginal submucosal dendritic cells, but not langerhans cells, induce protective Th1 responses to herpes simplex virus-2," Journal of Experimental Medicine, vol. 197, no. 2, pp. 153-162, 2003.

[116] R. S. Allan, C. M. Smith, G. T. Belz et al., "Epidermal viral immunity induced by $\mathrm{CD} 8 \alpha^{+}$dendritic cells but not by langerhans cells," Science, vol. 301, no. 5641, pp. 1925-1928, 2003.

[117] R. S. Allan, J. Waithman, S. Bedoui et al., "Migratory dendritic cells transfer antigen to a lymph node-resident dendritic cell population for efficient CTL priming," Immunity, vol. 25, no. 1 , pp. 153-162, 2006.
[118] H. K. Lee, M. Zamora, M. M. Linehan et al., "Differential roles of migratory and resident DCs in T cell priming after mucosal or skin HSV-1 infection," Journal of Experimental Medicine, vol. 206, no. 2, pp. 359-370, 2009.

[119] N. J. Moss, A. Magaret, K. J. Laing, A. S. Kask, M. Wang et al., "Peripheral blood CD4 T-cell and plasmacytoid dendritic cell (pDC) reactivity to herpes simplex virus 2 and $\mathrm{pDC}$ number do not correlate with the clinical or virologic severity of recurrent genital herpes," Journal of Virology, vol. 86, pp. 9952-9963, 2012.

[120] N. Hosken, P. McGowan, A. Meier et al., "Diversity of the CD8 ${ }^{+}$ T-cell response to herpes simplex virus type 2 proteins among persons with genital herpes," Journal of Virology, vol. 80, no. 11, pp. 5509-5515, 2006.

[121] Y. Nakanishi, B. Lu, C. Gerard, and A. Iwasaki, "CD8 ${ }^{+} \mathrm{T}$ lymphocyte mobilization to virus-infected tissue requires $\mathrm{CD} 4^{+}$ T-cell help," Nature, vol. 462, no. 7272, pp. 510-513, 2009.

[122] K. M. Khanna, R. H. Bonneau, P. R. Kinchington, and R. L. Hendricks, "Herpes simplex virus-specific memory $\mathrm{CD}^{+} \mathrm{T}$ cells are selectively activated and retained in latently infected sensory ganglia," Immunity, vol. 18, no. 5, pp. 593-603, 2003.

[123] T. Liu, K. M. Khanna, X. Chen, D. J. Fink, and R. L. Hendricks, "CD8 ${ }^{+} \mathrm{T}$ cells can block herpes simplex virus type 1 (HSV-1) reactivation from latency in sensory neurons," Journal of Experimental Medicine, vol. 191, no. 9, pp. 1459-1466, 2000.

[124] M. L. Freeman, B. S. Sheridan, R. H. Bonneau, and R. L. Hendricks, "Psychological stress compromises $\mathrm{CD}^{+}{ }^{+} \mathrm{T}$ cell control of latent herpes simplex virus type 1 infections," Journal of Immunology, vol. 179, no. 1, pp. 322-328, 2007.

[125] A. L. Cunningham, R. R. Turner, and A. C. Miller, "Evolution of recurrent herpes simplex lesions. An immunohistologic study," Journal of Clinical Investigation, vol. 75, no. 1, pp. 226-233, 1985.

[126] D. M. Koelle, C. M. Posavad, G. R. Barnum, M. L. Johnson, J. M. Frank et al., "Clearance of HSV-2 from recurrent genital lesions correlates with infiltration of HSV-specific cytotoxic T lymphocytes," Journal of Clinical Investigation, vol. 101, pp. 15001508, 1998.

[127] N. Iijima, M. M. Linehan, M. Zamora et al., "Dendritic cells and B cells maximize mucosal Th1 memory response to herpes simplex virus," Journal of Experimental Medicine, vol. 205, no. 13, pp. 3041-3052, 2008.

[128] L. M. Wakim, J. Waithman, N. Van Rooijen, W. R. Heath, and F. R. Carbone, "Dendritic cell-induced memory T cell activation in nonlymphoid tissues," Science, vol. 319, no. 5860, pp. 198-202, 2008.

[129] T. Peng, J. Zhu, K. Phasouk, D. M. Koelle, A. Wald et al., "An effector phenotype of $\mathrm{CD}^{+} \mathrm{T}$ cells at the junction epithelium during clinical quiescence of herpes simplex virus 2 infection," Journal of Virology, vol. 86, pp. 10587-10596, 2012.

[130] L. N. Sørensen, L. S. Reinert, L. Malmgaard, C. Bartholdy, A. R. Thomsen, and S. R. Paludan, "TLR2 and TLR9 synergistically control herpes simplex virus infection in the brain," Journal of Immunology, vol. 181, no. 12, pp. 8604-8612, 2008.

[131] E. A. Kurt-Jones, M. Chan, S. Zhou et al., "Herpes simplex virus 1 interaction with Toll-like receptor 2 contributes to lethal encephalitis," Proceedings of the National Academy of Sciences of the United States of America, vol. 101, no. 5, pp. 1315-1320, 2004.

[132] R. J. Soberman, C. R. Mackay, C. A. Vaine, G. B. Ryan, A. M. Cerny et al., "CD200R1 supports HSV-1 viral replication and licenses pro-inflammatory signaling functions of TLR2," PloS ONE, vol. 7, Article ID e47740, 2012. 
[133] U. K. Meyding-Lamade, C. Oberlinner, P. R. Rau et al., "Experimental herpes simplex virus encephalitis: a combination therapy of acyclovir and glucocorticoids reduces long-term magnetic resonance imaging abnormalities," Journal of NeuroVirology, vol. 9, no. 1, pp. 118-125, 2003.

[134] I. J. MacLeod and T. Minson, "Binding of herpes simplex virus type-1 virions leads to the induction of intracellular signalling in the absence of virus entry," PloS ONE, vol. 5, no. 3, Article ID e9560, 2010.

[135] M. Yoon, S. J. Kopp, J. M. Taylor, C. S. Storti, P. G. Spear, and W. J. Muller, "Functional interaction between herpes simplex virus type $2 \mathrm{gD}$ and HVEM transiently dampens local chemokine production after murine mucosal infection," PloS ONE, vol. 6, no. 1, Article ID e16122, 2011.

[136] M. G. Santoro, A. Rossi, and C. Amici, "NF- $\kappa$ B and virus infection: who controls whom," EMBO Journal, vol. 22, no. 11, pp. 2552-2560, 2003.

[137] J. R. Smiley, "Herpes simplex virus virion host shutoff protein: immune evasion mediated by a viral RNase?" Journal of Virology, vol. 78, no. 3, pp. 1063-1068, 2004.

[138] H. M. Friedman, G. H. Cohen, and R. J. Eisenberg, "Glycoprotein $\mathrm{C}$ of herpes simplex virus 1 acts as a receptor for the $\mathrm{C} 3 \mathrm{~b}$ complement component on infected cells," Nature, vol. 309, no. 5969, pp. 633-635, 1984.

[139] J. Lubinski, L. Wang, D. Mastellos, A. Sahu, J. D. Lambris, and H. M. Friedman, "In vivo role of complement-interacting domains of herpes simplex virus type $1 \mathrm{gC}$," Journal of Experimental Medicine, vol. 190, no. 11, pp. 1637-1646, 1999.

[140] J. Lubinski, T. Nagashunmugam, and H. M. Friedman, "Viral interference with antibody and complement," Seminars in Cell and Developmental Biology, vol. 9, no. 3, pp. 329-337, 1998.

[141] K. Ahn, T. H. Meyer, S. Uebel et al., "Molecular mechanism and species specificity of TAP inhibition by herpes simplex virus protein ICP47," EMBO Journal, vol. 15, no. 13, pp. 3247-3255, 1996.

[142] K. Fruh, K. Ahn, H. Djaballah et al., "A viral inhibitor of peptide transporters for antigen presentation," Nature, vol. 375, no. 6530, pp. 415-418, 1995.

[143] A. Hill, P. Juovic, I. York et al., "Herpes simplex virus turns off the TAP to evade host immunity," Nature, vol. 375, no. 6530, pp. 411-415, 1995.

[144] B. Levine, N. Mizushima, and H. W. Virgin, "Autophagy in immunity and inflammation," Nature, vol. 469, no. 7330, pp. 323335, 2011.

[145] B. Yordy, N. Iijima, A. Huttner, D. Leib, and A. Iwasaki, "A neuron-specific role for autophagy in antiviral defense against herpes simplex virus," Cell Host \& Microbe, vol. 12, pp. 334-345, 2012.

[146] N. P. Corbett, D. Blimkie, K. C. Ho et al., "Ontogeny of tolllike receptor mediated cytokine responses of human blood mononuclear cells," PloS ONE, vol. 5, no. 11, Article ID e15041, 2010.

[147] O. Vosters, C. Lombard, F. André, G. Sana, E. M. Sokal, and F. Smets, "The interferon-alpha and interleukin-10 responses in neonates differ from adults, and their production remains partial throughout the first 18 months of life," Clinical and Experimental Immunology, vol. 162, no. 3, pp. 494-499, 2010.

[148] S. Burl, J. Townend, J. Njie-Jobe et al., "Age-dependent maturation of toll-like receptor-mediated cytokine responses in gambian infants," PloS ONE, vol. 6, no. 4, Article ID e18185, 2011.
[149] B. J. Marais, "Childhood tuberculosis: epidemiology and natural history of disease," Indian Journal of Pediatrics, vol. 78, no. 3, pp. 321-327, 2011.

[150] C. B. Wilson, "Immunologic basis for increased susceptibility of the neonate to infection," Journal of Pediatrics, vol. 108, no. 1, pp. 1-12, 1986.

[151] P. R. Donald, B. J. Marais, and C. E. Barry, "Age and the epidemiology and pathogenesis of tuberculosis," The Lancet, vol. 375, no. 9729, pp. 1852-1854, 2010.

[152] A. Makrigiannakis, G. Petsas, B. Toth, K. Relakis, and U. Jeschke, "Recent advances in understanding immunology of reproductive failure," Journal of Reproductive Immunology, vol. 90, no. 1, pp. 96-104, 2011.

[153] J. S. Hunt, M. G. Petroff, R. H. McIntire, and C. Ober, "HLA-G and immune tolerance in pregnancy," FASEB Journal, vol. 19, no. 7, pp. 681-693, 2005.

[154] J. Szekeres-Bartho, "Regulation of NK cell cytotoxicity during pregnancy," Reproductive BioMedicine Online, vol. 16, no. 2, pp. 211-217, 2008.

[155] V. R. Aluvihare, M. Kallikourdis, and A. G. Betz, "Regulatory T cells mediate maternal tolerance to the fetus," Nature Immunology, vol. 5, no. 3, pp. 266-271, 2004.

[156] D. A. Somerset, Y. Zheng, M. D. Kilby, D. M. Sansom, and M. T. Drayson, "Normal human pregnancy is associated with an elevation in the immune suppressive $\mathrm{CD} 25^{+} \mathrm{CD} 4^{+}$regulatory T-cell subset," Immunology, vol. 112, no. 1, pp. 38-43, 2004.

[157] R. M. Samstein, S. Z. Josefowicz, A. Arvey, P. M. Treuting, and A. Y. Rudensky, "Extrathymic generation of regulatory T cells in placental mammals mitigates maternal-fetal conflict," Cell, vol. 150, pp. 29-38, 2012.

[158] J. E. Mold, J. Michaëlsson, T. D. Burt et al., "Maternal alloantigens promote the development of tolerogenic fetal regulatory $\mathrm{T}$ cells in utero," Science, vol. 322, no. 5907, pp. 1562-1565, 2008.

[159] J. H. Rowe, J. M. Ertelt, L. Xin, and S. S. Way, "Pregnancy imprints regulatory memory that sustains anergy to fetal antigen," Nature, vol. 490, pp. 102-106, 2012.

[160] L. Chabtini, B. Mfarrej, M. Mounayar, B. Zhu, I. Batal et al., "TIM-3 regulates innate immune cells to induce fetomaternal tolerance," Journal of Immunology, vol. 190, pp. 88-96, 2013.

[161] I. Roth, D. B. Corry, R. M. Locksley, J. S. Abrams, M. J. Litton, and S. J. Fisher, "Human placental cytotrophoblasts produce the immunosuppressive cytokine interleukin 10," Journal of Experimental Medicine, vol. 184, no. 2, pp. 539-548, 1996.

[162] J. Szekeres-Bartho, Z. Faust, P. Varga, L. Szereday, and K. Kelemen, "The immunological pregnancy protective effect of progesterone is manifested via controlling cytokine production," American Journal of Reproductive Immunology, vol. 35, no. 4, pp. 348-351, 1996.

[163] Z. A. Brown, A. Wald, R. A. Morrow, S. Selke, J. Zeh, and L. Corey, "Effect of serologic status and cesarean delivery on transmission rates of herpes simplex virus from mother to infant," Journal of the American Medical Association, vol. 289, no. 2, pp. 203-209, 2003.

[164] G. Marchini, S. Lindow, H. Brismar et al., “The newborn infant is protected by an innate antimicrobial barrier: peptide antibiotics are present in the skin and vernix caseosa," British Journal of Dermatology, vol. 147, no. 6, pp. 1127-1134, 2002.

[165] H. Yoshio, M. Tollin, G. H. Gudmundsson et al., "Antimicrobial polypeptides of human vernix caseosa and amniotic fluid: implications for newborn innate defense," Pediatric Research, vol. 53, no. 2, pp. 211-216, 2003. 
[166] H. Yoshio, H. Lagercrantz, G. H. Gudmundsson, and B. Agerberth, "First line of defense in early human life," Seminars in Perinatology, vol. 28, no. 4, pp. 304-311, 2004.

[167] T. Strunk, A. Currie, P. Richmond, K. Simmer, and D. Burgner, "Innate immunity in human newborn infants: prematurity means more than immaturity," Journal of Maternal-Fetal and Neonatal Medicine, vol. 24, no. 1, pp. 25-31, 2011.

[168] F. Cecconi, S. Di Bartolomeo, R. Nardacci et al., "A novel role for autophagy in neurodevelopment," Autophagy, vol. 3, no. 5, pp. 506-508, 2007.

[169] M. T. Viscomi and M. D’Amelio, “The, "janus-faced role" of autophagy in neuronal sickness: focus on neurodegeneration," Molecular Neurobiology, vol. 46, pp. 513-521, 2012.

[170] J. G. Lisciandro, S. L. Prescott, M. G. Nadal-Sims, C. J. Devitt, W. Pomat et al., "Ontogeny of Toll-like and NOD-like receptormediated innate immune responses in Papua New Guinean infants," PloS ONE, vol. 7, Article ID e36793, 2012.

[171] D. De Wit, S. Tonon, V. Olislagers et al., "Impaired responses to toll-like receptor 4 and toll-like receptor 3 ligands in human cord blood," Journal of Autoimmunity, vol. 21, no. 3, pp. 277-281, 2003.

[172] B. Cederblad and G. V. Alm, "Infrequent but efficient interferon- $\alpha$-producing human mononuclear leukocytes induced by herpes simplex virus in vitro studied by immuno-plaque and limiting dilution assays," Journal of Interferon Research, vol. 10, no. 1, pp. 65-73, 1990.

[173] M. E. Belderbos, O. Levy, F. Stalpers, J. L. Kimpen, L. Meyaard et al., "Neonatal plasma polarizes TLR4-mediated cytokine responses towards low IL-12p70 and high IL-10 production via distinct factors," PloS ONE, vol. 7, Article ID e33419, 2012.

[174] W. Al-Hertani, R. Y. Sen, D. M. Byers, and R. Bortolussi, "Human newborn polymorphonuclear neutrophils exhibit decreased levels of MyD88 and attenuated p38 phosphorylation in response to lipopolysaccharide," Clinical and Investigative Medicine, vol. 30, no. 2, pp. E44-E53, 2007.

[175] S. R. Yan, G. Qing, D. M. Byers, A. W. Stadnyk, W. Al-Hertani, and R. Bortolussi, "Role of MyD88 in diminished tumor necrosis factor alpha production by newborn mononuclear cells in response to lipopolysaccharide," Infection and Immunity, vol. 72, no. 3, pp. 1223-1229, 2004.

[176] P. P. Sarangi, B. Kim, E. Kurt-Jones, and B. T. Rouse, "Innate recognition network driving herpes simplex virus-induced corneal immunopathology: role of the toll pathway in early inflammatory events in stromal keratitis," Journal of Virology, vol. 81, no. 20, pp. 11128-11138, 2007.

[177] B. Danis, T. C. George, S. Goriely et al., "Interferon regulatory factor 7-mediated responses are defective in cord blood plasmacytoid dendritic cells," European Journal of Immunology, vol. 38, no. 2, pp. 507-517, 2008.

[178] E. Aksoy, V. Albarani, M. Nguyen et al., "Interferon regulatory factor 3-dependent responses to lipopolysaccharide are selectively blunted in cord blood cells," Blood, vol. 109, no. 7, pp. 28872893, 2007.

[179] S. Goriely, B. Vincart, P. Stordeur et al., "Deficient IL12(p35)gene expression by dendritic cells derived from neonatal monocytes," Journal of Immunology, vol. 166, no. 3, pp. 21412146, 2001.

[180] S. Goriely, C. Van Lint, R. Dadkhah et al., "A defect in nucleosome remodeling prevents IL-12(p35) gene transcription in neonatal dendritic cells," Journal of Experimental Medicine, vol. 199, no. 7, pp. 1011-1016, 2004.
[181] P. J. Vuillermin, A. L. Ponsonby, R. Saffery et al., "Microbial exposure, interferon gamma gene demethylation in naïve $\mathrm{T}$ cells, and the risk of allergic disease," Allergy, vol. 64, no. 3, pp. 348-353, 2009.

[182] O. Levy, M. Coughlin, B. N. Cronstein, R. M. Roy, A. Desai, and M. R. Wessels, "The adenosine system selectively inhibits TLRmediated TNF- $\alpha$ production in the human newborn," Journal of Immunology, vol. 177, no. 3, pp. 1956-1966, 2006.

[183] J. H. Dalle, J. Menezes, E. Wagner et al., "Characterization of cord blood natural killer cells: implications for transplantation and neonatal infections," Pediatric Research, vol. 57, no. 5, pp. 649-655, 2005.

[184] Y. Wang, H. Xu, X. Zheng, H. Wei, R. Sun, and Z. Tian, "High expression of NKG2A/CD94 and low expression of granzyme $\mathrm{B}$ are associated with reduced cord blood NK cell activity," Cellular \& Molecular Immunology, vol. 4, no. 5, pp. 377-382, 2007.

[185] M. Krampera, L. Tavecchia, F. Benedetti, G. Nadali, and G. Pizzolo, "Intracellular cytokine profile of cord blood T-, and NKcells and monocytes," Haematologica, vol. 85, no. 7, pp. 675-679, 2000.

[186] Y. Y. Fan, B. Y. Yang, and C. Y. Wu, "Phenotypic and functional heterogeneity of natural killer cells from umbilical cord blood mononuclear cells," Immunological Investigations, vol. 37, no. 1, pp. 79-96, 2008.

[187] J. Gaddy and H. E. Broxmeyer, "Cord blood CD16 ${ }^{+} 56^{-}$cells with low lytic activity are possible precursors of mature natural killer cells," Cellular Immunology, vol. 180, no. 2, pp. 132-142, 1997.

[188] S. S. Choi, V. S. Chhabra, Q. H. Nguyen, B. J. Ank, E. R. Stiehm, and R. L. Roberts, "Interleukin-15 enhances cytotoxicity, receptor expression, and expansion of neonatal natural killer cells in long-term culture," Clinical and Diagnostic Laboratory Immunology, vol. 11, no. 5, pp. 879-888, 2004.

[189] A. Nomura, H. Takada, C. H. Jin, T. Tanaka, S. Ohga, and T. Hara, "Functional analyses of cord blood natural killer cells and T cellsa distinctive interleukin-18 response," Experimental Hematology, vol. 29, no. 10, pp. 1169-1176, 2001.

[190] P. Satwani, J. Ayello, C. Van De Ven et al., "Immaturity of IL18 gene expression and protein production in cord blood (CB) versus peripheral blood (PB) mononuclear cells and differential effects in natural killer (NK) cell development and function," British Journal of Haematology, vol. 130, no. 2, pp. 284-292, 2005.

[191] S. M. Wood, H. G. Ljunggren, and Y. T. Bryceson, "Insights into NK cell biology from human genetics and disease associations," Cellular and Molecular Life Sciences, vol. 68, pp. 3479-3493, 2011.

[192] L. K. Dropulic and J. I. Cohen, "Severe viral infections and primary immunodeficiencies," Clinical Infectious Diseases, vol. 53, pp. 897-909, 2011.

[193] J. E. Mold, S. Venkatasubrahmanyam, T. D. Burt et al., "Fetal and adult hematopoietic stem cells give rise to distinct $\mathrm{T}$ cell lineages in humans," Science, vol. 330, no. 6011, pp. 1695-1699, 2010.

[194] Y. Ohshima and G. Delespesse, "T cell-derived IL-4 and dendritic cell-derived IL-12 regulate the lymphokine-producing phenotype of alloantigen-primed naive human CD4 T cells," Journal of Immunology, vol. 158, no. 2, pp. 629-636, 1997.

[195] M. C. Mingari, E. Maggi, A. Cambiaggi et al., "Development in vitro of human $\mathrm{CD} 4^{+}$thymocytes into functionally mature Th2 cells. Exogenous interleukin-12 is required for priming 
thymocytes to produce both Th1 cytokines and interleukin-10," European Journal of Immunology, vol. 26, no. 5, pp. 1083-1087, 1996.

[196] G. P. White, P. M. Watt, B. J. Holt, and P. G. Holt, “Differential patterns of methylation of the IFN- $\gamma$ promoter at CpG and non-CpG sites underlie differences in IFN- $\gamma$ gene expression between human neonatal and adult CD45RO- T cells," Journal of Immunology, vol. 168, no. 6, pp. 2820-2827, 2002.

[197] M. A. Fernandez, F. K. Puttur, Y. M. Wang, W. Howden, S. I. Alexander, and C. A. Jones, "T regulatory cells contribute to the attenuated primary $\mathrm{CD} 8^{+}$and $\mathrm{CD} 4^{+} \mathrm{T}$ cell responses to herpes simplex virus type 2 in neonatal mice," Journal of Immunology, vol. 180, no. 3, pp. 1556-1564, 2008.

[198] S. Ostrand-Rosenberg and P. Sinha, "Myeloid-derived suppressor cells: linking inflammation and cancer," Journal of Immunology, vol. 182, no. 8, pp. 4499-4506, 2009.

[199] J. I. Youn and D. I. Gabrilovich, "The biology of myeloid-derived suppressor cells: the blessing and the curse of morphological and functional heterogeneity," European Journal of Immunology, vol. 40, no. 11, pp. 2969-2975, 2010.

[200] E. Peranzoni, S. Zilio, I. Marigo et al., "Myeloid-derived suppressor cell heterogeneity and subset definition," Current Opinion in Immunology, vol. 22, no. 2, pp. 238-244, 2010.

[201] I. Poschke and R. Kiessling, "On the armament and appearances of human myeloid-derived suppressor cells," Clinical Immunology, vol. 144, pp. 250-268, 2012.

[202] D. I. Gabrilovich, S. Ostrand-Rosenberg, and V. Bronte, "Coordinated regulation of myeloid cells by tumours," Nature Reviews Immunology, vol. 12, pp. 253-268, 2012.

[203] S. Ostrand-Rosenberg, P. Sinha, D. W. Beury, and V. K. Clements, "Cross-talk between myeloid-derived suppressor cells (MDSC), macrophages, and dendritic cells enhances tumor-induced immune suppression," Seminars in Cancer Biology, vol. 22, pp. 275-281, 2012.

[204] Y. Hayashi, T. Wada, and R. Mori, "Protection of newborn mice against herpes simplex virus infection by prenatal and postnatal transmission of antibody," Journal of General Virology, vol. 64, no. 5, pp. 1007-1012, 1983.

[205] J. L. Yorty, S. A. Schultz, and R. H. Bonneau, "Postpartum maternal corticosterone decreases maternal and neonatal antibody levels and increases the susceptibility of newborn mice to herpes simplex virus-associated mortality," Journal of Neuroimmunology, vol. 150, no. 1-2, pp. 48-58, 2004.

[206] I. A. C. Evans and C. A. Jones, "Maternal immunization with a herpes simplex virus type 2 replication-defective virus reduces visceral dissemination but not lethal encephalitis in newborn mice after oral challenge," Journal of Infectious Diseases, vol. 185, no. 11, pp. 1550-1560, 2002.

[207] A. S. Yeager, A. M. Arvin, L. J. Urbani, and J. A. Kemp, "Relationship of antibody to outcome in neonatal herpes simplex virus infections," Infection and Immunity, vol. 29, no. 2, pp. 532-538, 1980.

[208] R. J. Whitley, A. J. Nahmias, and A. M. Visintine, "The natural history of herpes simplex virus infection of mother and newborn," Pediatrics, vol. 66, no. 4, pp. 489-494, 1980.

[209] J. Kahlon and R. J. Whitley, "Antibody response of the newborn after herpes simplex virus infection," Journal of Infectious Diseases, vol. 158, no. 5, pp. 925-933, 1988.

[210] Z. A. Brown, L. A. Vontver, and J. Benedetti, "Effects on infants of a first episode of genital herpes during pregnancy," The New England Journal of Medicine, vol. 317, no. 20, pp. 1246-1251, 1987.
[211] L. R. Stanberry, "Clinical trials of prophylactic and therapeutic herpes simplex virus vaccines," Herpes, vol. 11, no. 3, pp. 161A169A, 2004.

[212] R. B. Belshe, P. A. Leone, D. I. Bernstein, A. Wald, M. J. Levin et al., "Efficacy results of a trial of a herpes simplex vaccine," The New England Journal of Medicine, vol. 366, pp. 34-43, 2012.

[213] L. Corey, A. G. M. Langenberg, R. Ashley et al., "Recombinant glycoprotein vaccine for the prevention of genital HSV-2 infection: two randomized controlled trials," Journal of the American Medical Association, vol. 282, no. 4, pp. 331-340, 1999.

[214] L. R. Stanberry, S. L. Spruance, A. L. Cunningham et al., "Glycoprotein-D-adjuvant vaccine to prevent genital herpes," The New England Journal of Medicine, vol. 347, no. 21, pp. 1652-1661, 2002.

[215] A. J. Lee and A. A. Ashkar, "Herpes simplex virus-2 in the genital mucosa: insights into the mucosal host response and vaccine development," Current Opinion in Infectious Diseases, vol. 25, pp. 92-99, 2012.

[216] S. E. Straus, L. Corey, R. L. Burke et al., "Placebo-controlled trial of vaccination with recombinant glycoprotein $\mathrm{D}$ of herpes simplex virus type 2 for immunotherapy of genital herpes," The Lancet, vol. 343, no. 8911, pp. 1460-1463, 1994.

[217] H. Shin and A. Iwasaki, "A vaccine strategy that protects against genital herpes by establishing local memory T cells," Nature, vol. 491, pp. 463-467, 2012.

[218] K. Olson, P. Macias, S. Hutton, W. A. Ernst, G. Fujii, and J. P. Adler-Moore, "Liposomal gD ectodomain $\left(\mathrm{gD}_{1-306}\right)$ vaccine protects against HSV2 genital or rectal infection of female and male mice," Vaccine, vol. 28, no. 2, pp. 548-560, 2009.

[219] L. Macmillan, G. O. Ifere, Q. He et al., "A recombinant multivalent combination vaccine protects against Chlamydia and genital herpes," FEMS Immunology and Medical Microbiology, vol. 49, no. 1, pp. 46-55, 2007.

[220] I. Bettahi, X. Zhang, R. E. Afifi, and L. Benmohamed, "Protective immunity to genital herpes simplex virus type 1 and type 2 provided by self-adjuvanting lipopeptides that drive dendritic cell maturation and elicit a polarized Th1 immune response," Viral Immunology, vol. 19, no. 2, pp. 220-236, 2006.

[221] C. S. Morello, M. S. Levinson, K. A. Kraynyak, and D. H. Spector, "Immunization with Herpes Simplex Virus 2 (HSV-2) genes plus inactivated HSV-2 is highly protective against acute and recurrent HSV-2 disease," Journal of Virology, vol. 85, no. 7, pp. 3461-3472, 2011.

[222] A. S. Kask, X. Chen, J. O. Marshak et al., "DNA vaccine delivery by densely-packed and short microprojection arrays to skin protects against vaginal HSV-2 challenge," Vaccine, vol. 28, no. 47, pp. 7483-7491, 2010.

[223] T. Dudek and D. M. Knipe, "Replication-defective viruses as vaccines and vaccine vectors," Virology, vol. 344 , no. 1, pp. 230239, 2006.

[224] D. M. Koelle, "Vaccines for herpes simplex virus infections," Current Opinion in Investigational Drugs, vol. 7, no. 2, pp. 136$141,2006$.

[225] Y. Hoshino, S. K. Dalai, K. Wang et al., "Comparative efficacy and immunogenicity of replication-defective, recombinant glycoprotein, and DNA vaccines for herpes simplex virus 2 infections in mice and guinea pigs," Journal of Virology, vol. 79, no. 1, pp. 410-418, 2005.

[226] N. J. Reszka, T. Dudek, and D. M. Knipe, "Construction and properties of a herpes simplex virus 2 dl5-29 vaccine candidate strain encoding an HSV-1 virion host shutoff protein," Vaccine, vol. 28, no. 15, pp. 2754-2762, 2010. 
[227] W. P. Halford, R. Püschel, E. Gershburg, A. Wilber, S. Gershburg, and B. Rakowski, "A live-attenuated HSV-2 ICP0- virus elicits 10 to 100 times greater protection against genital herpes than a glycoprotein D subunit vaccine," PloS ONE, vol. 6, no. 3, Article ID e17748, 2011.

[228] S. Awasthi, E. E. Zumbrun, H. Si, F. Wang, C. E. Shaw et al., "Live attenuated herpes simplex virus 2 glycoprotein E deletion mutant as a vaccine candidate defective in neuronal spread," Journal of Virology, vol. 86, pp. 4586-4598, 2012.

[229] R. Brans and F. Yao, "Immunization with a dominant-negative recombinant Herpes Simplex Virus (HSV) type 1 protects against HSV-2 genital disease in guinea pigs," BMC Microbiology, vol. 10, article 163, 2010.

[230] J. E. Schrimpf, E. M. Tu, H. Wang, Y. M. Wong, and L. A. Morrison, "B7 costimulation molecules encoded by replicationdefective, vhs-deficient HSV-1 improve vaccine-induced protection against corneal disease," PloS ONE, vol. 6, no. 8, Article ID e22772, 2011.

[231] S. P. Vagvala, L. G. Thebeau, S. R. Wilson, and L. A. Morrison, "Virus-encoded B7-2 costimulation molecules enhance the protective capacity of a replication-defective herpes simplex virus type 2 vaccine in immunocompetent mice," Journal of Virology, vol. 83, no. 2, pp. 953-960, 2009.

[232] S. W. Lee, P. F. Markham, M. J. Coppo, A. R. Legione, J. F. Markham et al., "Attenuated vaccines can recombine to form virulent field viruses," Science, vol. 337, article 188, 2012.

[233] M. de Veer and E. Meeusen, "New developments in vaccine research-unveiling the secret of vaccine adjuvants," Discovery Medicine, vol. 12, pp. 195-204, 2011.

[234] F. Superti, M. G. Ammendolia, and M. Marchetti, "New advances in anti-HSV chemotherapy," Current Medicinal Chemistry, vol. 15, no. 9, pp. 900-911, 2008.

[235] L. V. Kovalchuk, L. V. Gankovskaya, O. A. Gankovskaya, and V. F. Lavrov, "Herpes simplex virus: treatment with antimicrobial peptides," Advances in Experimental Medicine and Biology, vol. 601, pp. 369-376, 2007.

[236] R. B. Basak, V. Malpani, K. Kakish, S. Vargese, N. Chauhan et al., "Poor neurological sequelae of herpes simplex virus encephalitis in an infant despite adequate antiviral and adjunct corticosteroid therapy," Indian Journal of Dermatology, vol. 56, pp. 749751, 2011.

[237] H. Openshaw and E. M. Cantin, "Corticosteroids in herpes simplex virus encephalitis," Journal of Neurology, Neurosurgery and Psychiatry, vol. 76, no. 11, pp. 1469-1471, 2005.

[238] J. P. Wang, G. N. Bowen, S. Zhou, A. Cerny, A. Zacharia et al., "Role of specific innate immune responses in herpes simplex virus infection of the central nervous system," Journal of Virology, vol. 86, pp. 2273-2281, 2012.

[239] A. H. J. van den Biggelaar, S. L. Prescott, M. Roponen et al., "Neonatal innate cytokine responses to BCG controlling T-cell development vary between populations," Journal of Allergy and Clinical Immunology, vol. 124, no. 3, pp. 544.e2-550.e2, 2009. 


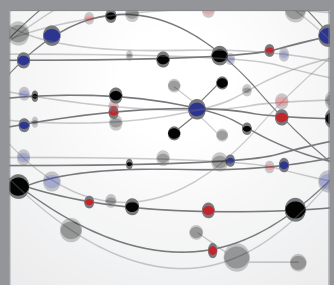

The Scientific World Journal
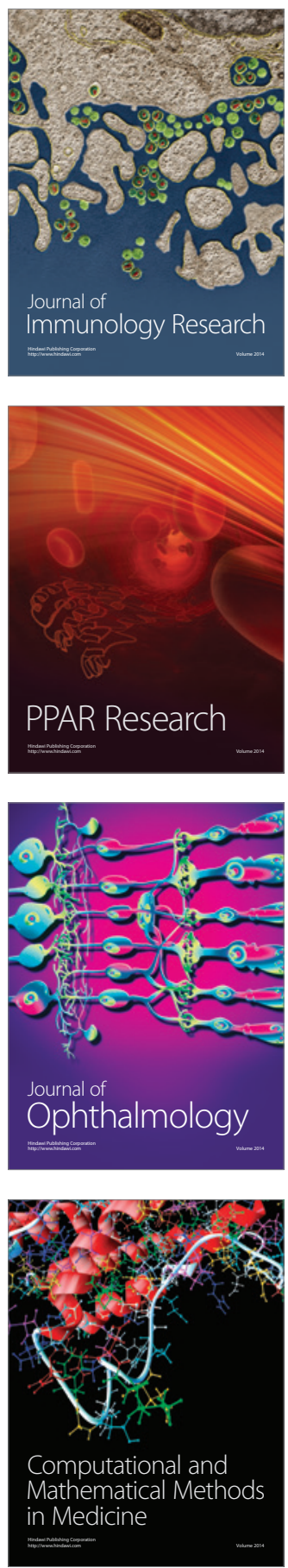

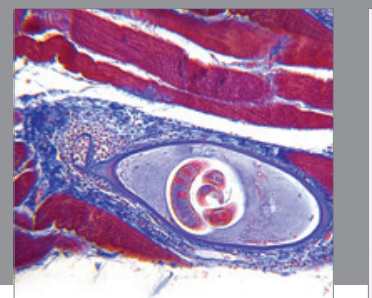

Gastroenterology

Research and Practice
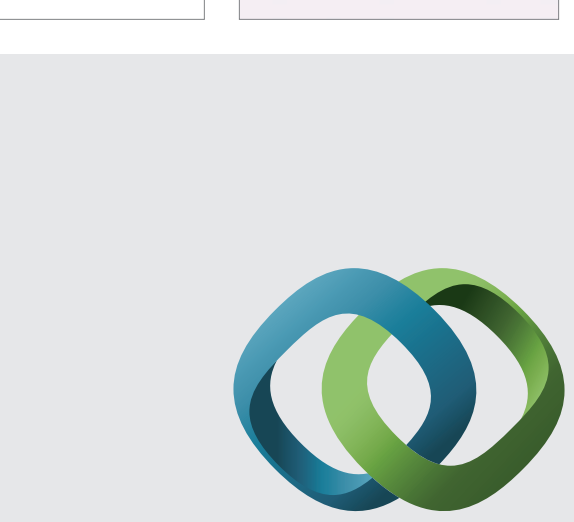

\section{Hindawi}

Submit your manuscripts at

http://www.hindawi.com
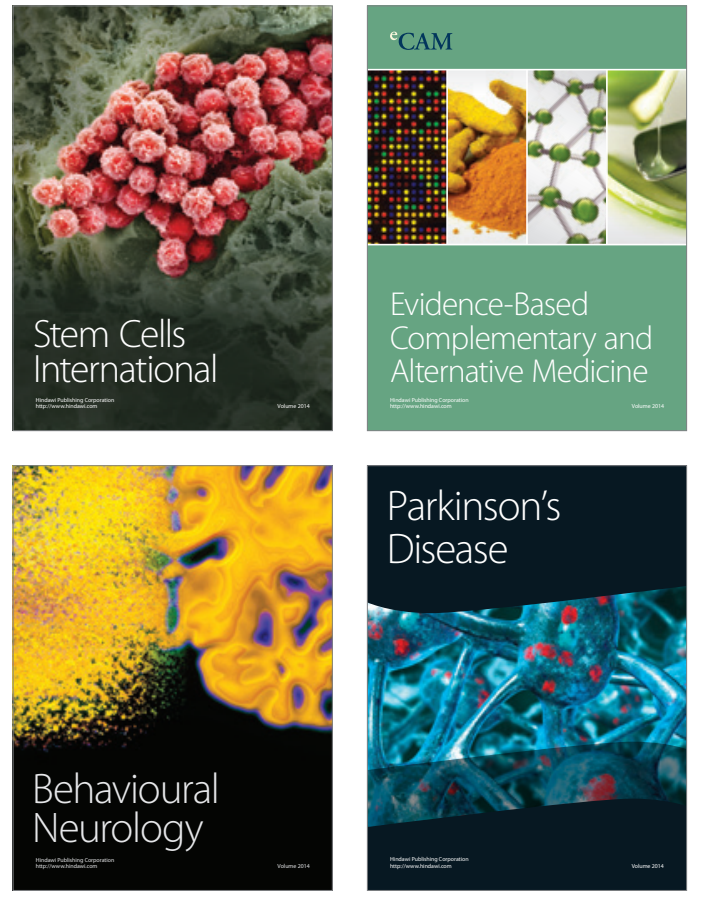
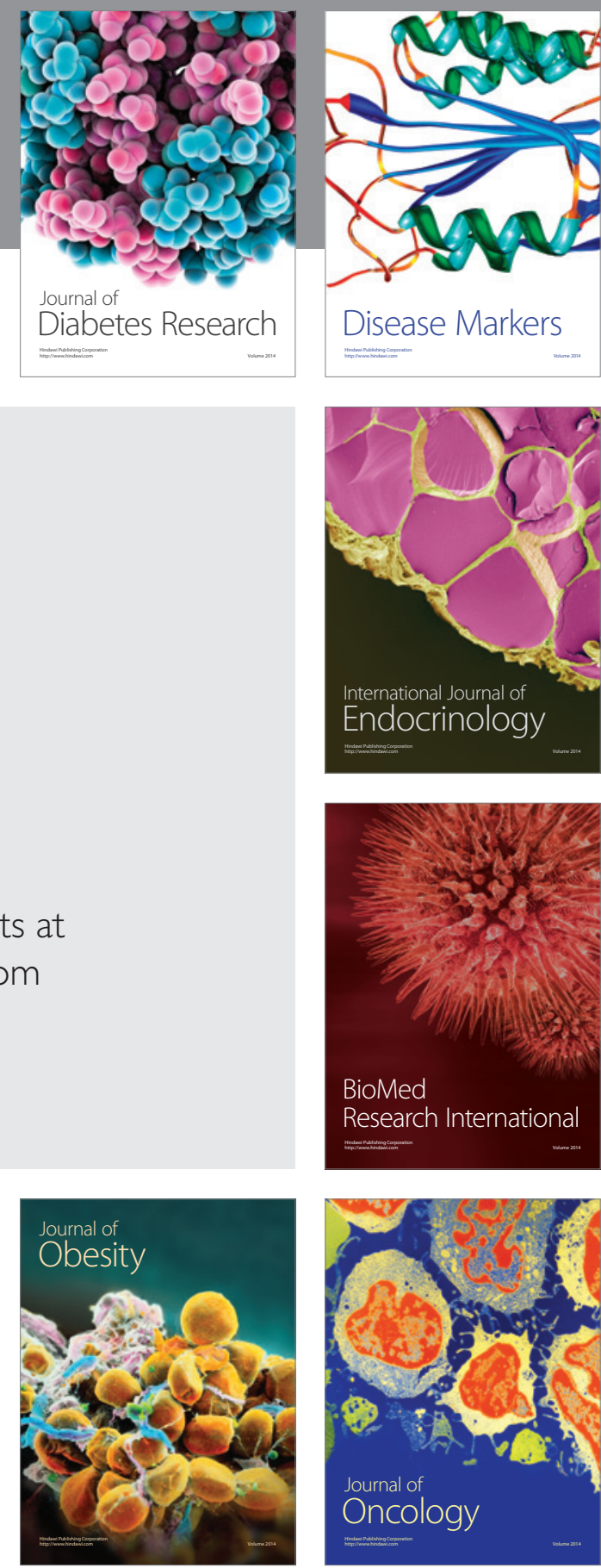

Disease Markers
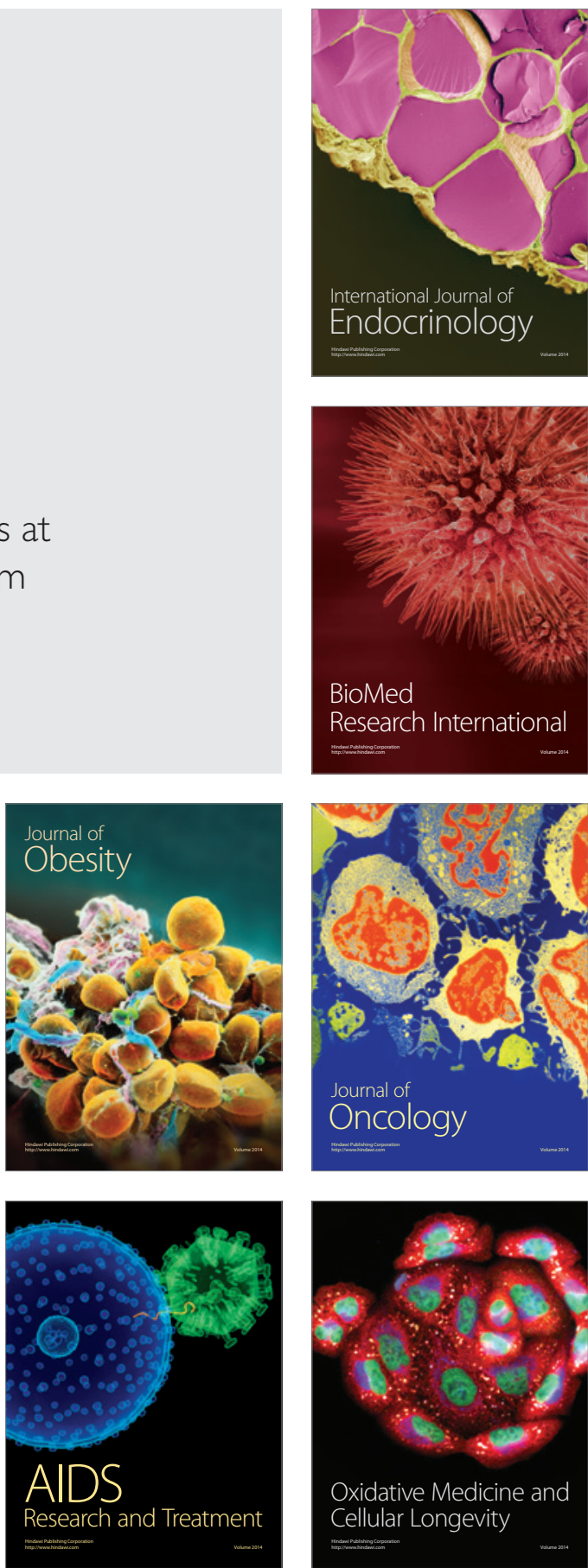